IZA DP No. 7417

Homeownership and Entrepreneurship:

The Role of Commitment and Mortgage Debt

Philippe Bracke

Christian Hilber

Olmo Silva

May 2013 


\title{
Homeownership and Entrepreneurship: The Role of Commitment and Mortgage Debt
}

\author{
Philippe Bracke \\ SERC, London School of Economics \\ Christian Hilber \\ SERC, London School of Economics \\ Olmo Silva \\ SERC, London School of Economics \\ and IZA
}

Discussion Paper No. 7417

May 2013

IZA

P.O. Box 7240

53072 Bonn

Germany

Phone: +49-228-3894-0

Fax: +49-228-3894-180

E-mail: iza@iza.org

\begin{abstract}
Any opinions expressed here are those of the author(s) and not those of IZA. Research published in this series may include views on policy, but the institute itself takes no institutional policy positions. The IZA research network is committed to the IZA Guiding Principles of Research Integrity.

The Institute for the Study of Labor (IZA) in Bonn is a local and virtual international research center and a place of communication between science, politics and business. IZA is an independent nonprofit organization supported by Deutsche Post Foundation. The center is associated with the University of Bonn and offers a stimulating research environment through its international network, workshops and conferences, data service, project support, research visits and doctoral program. IZA engages in (i) original and internationally competitive research in all fields of labor economics, (ii) development of policy concepts, and (iii) dissemination of research results and concepts to the interested public.
\end{abstract}

IZA Discussion Papers often represent preliminary work and are circulated to encourage discussion. Citation of such a paper should account for its provisional character. A revised version may be available directly from the author. 


\title{
ABSTRACT \\ Homeownership and Entrepreneurship: The Role of Commitment and Mortgage Debt ${ }^{\star}$
}

\begin{abstract}
We study the link between homeownership and entrepreneurship using a model of occupational choice and housing tenure where homeowners commit a fixed budget to mortgage payments. Our model predicts that: (i) mortgage commitments, by amplifying risk aversion, diminish the likelihood that homeowners start a business; (ii) the negative link between homeownership and entrepreneurship is increasing in mortgage debt; and (iii) the negative relation is more pronounced for entrepreneurs in risky sectors. Exploiting the longitudinal dimension of the British Household Panel Survey to control for unobservables, we test and confirm these predictions. Leveraged home-buyers are $30 \%$ less likely to become entrepreneurs.
\end{abstract}

JEL Classification: L26, D14, G11, R21

Keywords: entrepreneurship, homeownership, commitment

Corresponding author:

Olmo Silva

Department of Geography and Environment

London School of Economics

Houghton Street

London, WC2A 2AE

United Kingdom

E-mail: o.silva@Ise.ac.uk

\footnotetext{
* We would like to thank Tom Davidoff, David De Meza, Rob Fairlie, Ed Glaeser, Erik Hurst, Josh Lerner, Henry Overman, Roberto Picchizzolu, Steve Pischke, Yona Rubinstein, Todd Sinai, Will Strange and seminar and conference participants at Brown University, Centre for Economic Performance (CEP/LSE), Harvard Business School, Harvard Kennedy School, IZA Workshop on Entrepreneurship Research 2011, LSE Economic Geography work-in-progress meetings, NARSC Annual Meetings 2011, SERC Annual Conference 2011, IZA/CEPR European Summer Symposium in Labour Economics 2012, Stirling University and University of Barcelona for their helpful comments and suggestions. We are responsible for any errors or omissions.
} 


\section{Introduction}

Owner-occupied housing is the single biggest asset in most households' balance sheet and has considerable effects on their portfolio allocation. Extensive research has highlighted its impact on a household's exposure to risky assets (Flavin and Yamashita, 2002; Cocco, 2005; Chetty and Szeidl, 2010). Housing also has an effect on the allocation of human capital in the labor market, mostly because homeowners are less mobile than renters (e.g., Oswald, 1996; Munch et al., 2006; Ferreira et al., 2010). A few studies have documented positive externalities stemming from owner-occupation: homeownership encourages civic engagement (e.g., DiPasquale and Glaeser, 1999; Hoff and Sen, 2005); homeowners are more motivated to control local government (e.g., Fischel, 2001; Dehring et al., 2008), and homeowners pay greater attention towards environmental issues and children's education (Dietz and Haurin, 2003). ${ }^{1}$ Partly because of these positive externalities, most developed countries have adopted tax policies aimed at promoting homeownership over the past decades. ${ }^{2}$

Similarly, since the writings of Schumpeter (1921), entrepreneurship has been broadly associated with positive economic outcomes - including job creation, innovation, and economic growth (Michelacci, 2003; Acs and Carlsson, 2004) - and governments around the world have implemented policies aimed at promoting business start-ups. However, entrepreneurship is not only a labor market decision: it is also an investment choice to be analyzed in the context of portfolio allocation. For example, Heaton and Lucas (2000) and Faig and Shum (2002) show that households who run their own businesses choose safer assets for their financial portfolios.

In this paper we expand on and combine these two strands of the literature to study the link between homeownership and entrepreneurship. We do so by first providing a theoretical framework that formalizes the entrepreneurial decision of homeowners and renters in the context of portfolio allocation, and then by testing its predictions using the British Household Panel Survey (BHPS) for the period 1991-2008.

We put forward a model of labor income and housing tenure choice in which individuals derive utility from the consumption of a standard composite good and housing. Renters are free to adjust their housing consumption vis-a-vis shocks to their labor income; by contrast, homeowners must commit to a fixed amount of housing. The underlying economic rationale for this assumption is that homeowners, in contrast to renters, face high housing transaction costs, which prevents them from adjusting housing consumption. Conditional on their housing tenure, agents in our model choose between an occupation as dependent workers or as entrepreneurs. Consistently with our subsequent empirical analysis and with previous evidence (Hamilton, 2000), we assume that the income of entrepreneurs has a higher variance, making entrepreneurship more risky than dependent employment.

Our model yields three predictions. First, for reasonable levels of mortgage costs, the link between homeownership and entrepreneurship is negative. Second, this link becomes more negative as mortgage debt increases. Third, the negative relationship between homeownership and entrepreneurship is more pronounced when considering entrepreneurs who choose to work in riskier sectors (i.e. where profits are more volatile).

The main intuition behind these results can be summarized as follows: when agents commit to mortgage payments, income variations get fully translated into consumption variations instead of being

\footnotetext{
${ }^{1}$ More recently, Hilber and Mayer (2009), looking at investments in local public schools, and Hilber (2010), focusing on individual neighborhood-specific social capital investments, document that the positive link between homeownership and these investments is mainly confined to areas where the supply of land available for new development is scarce (i.e., in places with more inelastic supply of housing).

${ }^{2}$ Government-induced incentives include tax relief on mortgage interest payments, low or no taxes on imputed rents, non-taxation of capital gains on principally owner-occupied dwellings, and subsidies to low-income families to reduce the financing cost of homeownership.
} 
smoothed out between consumption and housing (Chetty and Szeidl, 2007). As a consequence, all else equal, homeowners are effectively more reluctant than renters to choose risky sources of income, such as entrepreneurship. Stated differently, investments in homeownership crowd out investments in entrepreneurship.

An important feature of our model is that we allow individuals to differ in unobserved ways in their innate taste for entrepreneurship and in the extent of mortgage debt used to finance their housing purchase. In our setting some homeowners with mortgages will still decide to start a business because of their innate preference for being entrepreneurs. This implies that in our empirical analysis it is crucial to control for unobserved individual characteristics using a fixed-effects strategy.

To test the predictions of the model, we exploit the longitudinal dimension of the British Household Panel Survey (BHPS) covering the period between 1991 and 2008. The structure of the BHPS allows us to construct a detailed monthly-spell dataset that tracks individuals' job histories and tenure choices, coupled with information on time-varying background characteristics. We use this data to estimate regressions that identify the precise timing of individuals' transitions into homeownership and entrepreneurial jobs. Our data reveals that a higher percentage of people transits into homeownership than into entrepreneurship, and at an earlier age. Thus it seems natural to focus on the relation between homeownership and entrepreneurship in this order.

One empirical concern is the need to distinguish between genuine entrepreneurship and other kinds of self-employment (Hurst and Pugsley, 2011; Faggio and Silva, 2011). In this paper, we define entrepreneurs as self-employed individuals with dependent workers. By doing so, we are able to study the link between homeownership and genuine entrepreneurship, rather than 'self-employment out of necessity' or as a last-resort option (Alba-Ramirez, 1994; Martinez-Granado, 2002).

Simple OLS estimates indicate a positive association between homeownership and entrepreneurship. However, once we use fixed effects to control for time-invariant unobservables - such as innate entrepreneurial preference or persistent wealth - we find that homeownership is significantly negatively associated with entrepreneurship, as predicted by our model. The magnitude of this relation is sizable; individuals who become homeowners are 20-25\% less likely to become entrepreneurs.

Our empirical analysis reveals that the negative link between homeownership and entrepreneurship remains strong and significant for up to 48 months after purchasing a house - when leverage is likely to be at its highest - and then wanes out. However, we find no evidence that the link between homeownership and entrepreneurship turns positive and significant as time goes by. Our results also indicate that the negative link between homeownership and entrepreneurship is anticipated 12-18 months before the actual purchase of a house. This is consistent with our model of tenure choice with commitment (see Engelhardt, 1996, for evidence of anticipated effects of commitment on consumption).

To provide further evidence in support of our model, we focus on the role of mortgage debt and show that the negative relation between homeownership and entrepreneurship holds only for homeowners with mortgages. Moreover, we exploit data on households' housing-related debt to show that the negative relation between homeownership and entrepreneurship is stronger when leverage is high. In particular, using within-individual time-varying information on the loan-to-value (LTV) ratio of the mortgage, we find that a one standard deviation increase in the LTV is associated with an $8.3 \%$ reduction in the probability of being an entrepreneur. Using alternative measures of mortgage debt - such as the extent of monthly mortgage payments - yields similar results. This finding is fully consistent with the second prediction of our model.

To address concerns about endogeneity in our estimates of the link between an individual's LTV and entrepreneurship, we devise an instrumental variable (IV) strategy based on information on the LTV of 
newly originated mortgages in the area of an individual's residence obtained from the Survey of Mortgage Lenders (SML). We use this information to predict an individual's LTV exploiting the intuition that most of the mortgage financing conditions are dictated by the local housing market and banking circumstances (see Muelbauer, 2002). To account for local economic cycles, we further control for local house prices. Our fixed-effects IV strategy fully confirms our previous findings.

Finally, we directly assess whether homeowners shy away from riskier entrepreneurial ventures. To do so, we collect data on company profits at a detailed sectoral level and construct a series of proxies for the riskiness of entrepreneurial ventures based on profit variability. Using this information, we show that the negative link between homeownership and entrepreneurship holds for individuals operating in risky sectors, but not for entrepreneurs working in industries with lower profit variability. This provides empirical support for the third prediction of our model.

Our findings could also be consistent with a theory based on credit constraints, whereby leveraged home-buyers are prevented from taking on additional credit to start a business. However, for this explanation to hold true, we should detect a positive relationship between house price increases and entry into entrepreneurship. This is because, as home values increase, LTV ratios are pushed down and housing becomes collateral that can be used to borrow and relax credit constraints in the start-up decision.

Contrary to this view, we find that local house price variation has no explanatory power in our analysis and cannot reverse the negative link between homeownership and entrepreneurship. In particular, we show that capital gains accrued on owner-occupied housing do not enter our regressions significantly. This is so irrespective of whether we measure capital gains using local house prices or self-reported housing values, and irrespective of whether we follow Chetty and Szeidl (2010) and instrument housing value appreciation using national house price variation in interaction with proxies for the local elasticity of housing supply. This finding is very similar to Hurst and Lusardi (2004) and Disney and Gathergood (2009) and casts doubt on the view that credit constraints play a role in explaining our results.

To the best of our knowledge, our study is the first to cast the link between homeownership and entrepreneurship in an occupational choice model with housing commitment and financial leverage, and the first to document that homeownership can crowd out entrepreneurship. Two other papers that explicitly investigate the link between homeownership and entrepreneurship using micro-level data are Fairlie (2010) and Wang (2012). While the former presents cross-sectional evidence for the US suggesting that homeownership has a small positive effect on business creation (consistent with our OLS results), the latter investigates the effects on entrepreneurship of a policy that allowed Chinese public-sector employees renting state-owned housing to buy their properties at subsidized prices. More recently, Harding and Rosenthal (2013) provide cross-sectional evidence suggesting that house price gains experienced by homeowners promote entrepreneurship among older individuals aged above 50, where leverage and commitment considerations are likely to be unimportant. Finally, Adelino et al. (2013) use US data at the MSA level to show that areas with faster house price appreciation between 2002 and 2007 experienced stronger increases in small business employment compared to employment growth at larger establishments. The authors also present evidence that larger house price increases led to more business start-ups. We believe the discrepancy between their findings and ours can be explained by the fact that our results mainly capture a medium-run trade-off between homeownership and entrepreneurship in the presence of commitment and financial leverage. This cannot be detected using aggregated data that lack detailed information on a household's leverage, and cannot track an individual's tenure and employment transitions.

Our paper is structured as follows. The next Section discusses the related literature. Section 3 
illustrates our theoretical framework. In Sections 4 and 5 we describe how we use the BHPS to construct a monthly-spell panel and present descriptive statistics. Section 6 discusses our main findings on the link between homeownership and entrepreneurship. Section 7 explores different mechanisms and explanations for our key results. Finally, we provide some concluding remarks in Section 8.

\section{Related literature}

Our findings contribute to three strands of the literature: the link between homeownership, entrepreneurship and portfolio choices; the effects of homeownership on labor market outcomes; and the role of credit constraints in entrepreneurship.

Both housing and entrepreneurship play a prominent role in the context of portfolio decisions. Henderson and Ioannides (1983) were the first to formulate the proposition that owner-occupiers over-invest in housing, while Brueckner (1997) demonstrated that when the investment constraint induced by owneroccupied housing is binding, homeowners cannot adequately diversify their portfolio. Flavin and Yamashita (2002) examine a household portfolio problem when housing matters both as consumption and investment. They find that the optimal consumption level might exceed the optimal investment quantity. More recently, Cocco (2005) and Chetty and Szeidl (2010) show that homeownership - and in particular homeownership associated with large mortgages - significantly reduces a household's exposure to risky assets, such as stocks. Our results are consistent with the logic presented in this strand of the literature: home-buyers engage in an illiquid and large investment - with a hard-to-hedge risk - and this leaves less room for investment in risky entrepreneurial ventures.

In a similar vein, Heaton and Lucas (2000) show that running a private business has a significant impact on portfolio choices. Entrepreneurs invest proportionally less in stocks than other dependent workers, especially if they own a significant stake in the business they run. Faig and Shum (2002) bring together housing and entrepreneurial ventures in their analysis and show that households who plan to invest in one of these two activities - which they call "illiquid projects" - hold significantly safer portfolios. This is because, since entrepreneurship and housing are both highly illiquid, those households need a portfolio of liquid assets, which can be readily sold, in order to face the liquidity needs.

However, entrepreneurship is not just an investment decision but also a labor market choice. Several studies have highlighted the effects of homeownership on labor market outcomes. In a series of seminal articles Oswald $(1996,1998,1999)$ challenged the wisdom of polices promoting homeownership suggesting that high rates of homeownership are associated to higher levels of unemployment. His conjecture was that, since homeowners are less mobile than renters, they are less likely to move to find an alternative occupation if they lose their current job because of geographically/sector asymmetric shocks. These seminal articles remain highly controversial and have initiated a large body of literature that studies the impact of housing tenure on both unemployment incidence and unemployment duration. In two recent articles, Munch et al. (2006) and Battu and Phimister (2008) use duration models applied to micro-level data for Denmark and the UK respectively to investigate these issues. Although their evidence supports Oswald's conjecture that homeowners are less geographically mobile, the authors find no evidence that homeowners are more likely to become unemployed or have longer unemployment spells. The recent financial crisis and housing bust that hit a number of OECD countries (in particular, the US) has reignited the debate on the benefits (or detriments) of homeownership. In a recent paper, Ferreira et al. (2010) show that owners in negative-equity are significantly less mobile, and suggest that this has significant implications for the design of public policies. Our results present a previously undocumented 
externality of homeownership on labor market outcomes, namely a negative link with entrepreneurship.

Finally, our work touches upon the large empirical literature that investigates the role played by credit constraints in the decision to become an entrepreneur (Evans and Jovanovic, 1989; Holtz-Eakin and Rosen, 1994; Blanchflower and Oswald, 1998; Taylor, 2001; Michelacci and Silva, 2007; Fairlie and Krashinsky, 2011). In two related studies using UK macro-data, Black et al. (1996) point out that bank loans are often secured on an entrepreneur's house, and, De Meza and Webb (1999) argue that liquidity constraints play a major role in determining who sets up a business and that capital-market failure holds back enterprise. ${ }^{3}$ A remarkable dissenting view is provided by Hurst and Lusardi (2004), who suggest that the relation between wealth and entrepreneurship is only significant at the very top of the wealth distribution. Moreover, they find that households living in areas which experience strong house price appreciation are not significantly more likely to start an entrepreneurial venture. ${ }^{4}$ This result, which we replicate using UK data, questions the relevance of credit constraints in determining entry into entrepreneurship.

\section{Theoretical framework}

This section develops a model of occupation choice as a function of tenure status. The first part of this section presents the assumptions of the model, while the second part presents the model propositions. The main insight from the model is that, conditional on individual characteristics and preferences, being a homeowner reduces the likelihood of being an entrepreneur. This occurs because homeownership entails a commitment to mortgage payments that increases the effect of income risk on an individual's utility (as in Chetty and Szeidl, 2007). Therefore homeowners avoid occupations where income risk is greatest, such as risky entrepreneurial activities.

\subsection{Model assumptions}

We assume that individuals derive utility from the consumption of a standard composite good $(C)$ and housing $(H): U(C, H)$, with the usual conditions that $U_{C}>0, U_{C C}<0, U_{H}>0, U_{H H}<0$, and all these derivatives are continuous. In what follows we exploit two further conditions. First, we assume that the cross-derivative of the utility function is non-negative, i.e. $U_{C H} \geq 0$. This condition is consistent with the literature on consumption commitments (Chetty and Szeidl, 2007) and has been extensively used and documented in both the macro and micro finance literature (Lustig and Nieuwerburgh, 2005; Piazzesi et al., 2007; Flavin and Nakagawa, 2008). Further empirical evidence suggests that household expenditure in housing is a constant fraction of income (Davis and Ortalo-Magné, 2011), which is consistent with utility functions, such as Cobb-Douglas ones, where $U_{C H} \geq 0$. Second, we assume prudence in the consumption of the standard composite good, i.e. the third derivative of the utility function with respect to $C$ is positive: $U_{C C C}>0$. This is equivalent to requiring that additional risk reduces consumption, and it is a common condition in the macro literature on precautionary savings (Shore and Sinai, 2010).

We envisage a 1-period setting, in which agents maximize their utility under a budget constraint. An important assumption of our model is that, while renters can freely adjust the amount of housing

\footnotetext{
${ }^{3}$ The view that homeownership helps entrepreneurship is also popular among policymakers and the media. The US Department of Housing and Development stated that "through homeownership a family (...) invests in an asset that can (...) provide the capital needed to start a small business" (HUD 1995). Similar claims have been put forward in the UK policy environment (see BIS 2010). Finally, the media have amplified the resonance of this debate by arguing that politicians designing housing policies should bear in mind that "homeownership is a key factor in being able to finance (...) a small-business, expand an existing business, or keep a business alive" (USA Today, 2011).

${ }^{4} \mathrm{~A}$ similar result is presented in Disney and Gathergood (2009) using British data.
} 
consumed vis-a-vis shocks to their income, homeowners are forced to stick to a fixed amount $\bar{H}$. This assumption captures, in a stark way, the high mobility and transaction costs associated with homeownership (Haurin and Gill, 2002). Clearly, transactions costs are not infinite and in practice homeowners do trade their houses. We restrict our analysis to this limiting assumption for the sake of clarity. ${ }^{5}$

For renters, the budget constraint is:

$$
Y=C+r H
$$

where $r$ is the relative price of one unit of housing (the rent) with respect to consumption. For simplicity, we assume that $r$ is the same for all individuals. For owners, the budget constraint is:

$$
Y=C+m_{i} \bar{H},
$$

where the quantity of housing is fixed and the price of housing is denoted as $m_{i}$ to highlight the fact that the biggest chunk of the price of consuming housing, for homeowners, is made of mortgage payments. Note that we allow $m_{i}$ to vary across individuals as indicated by the subscript $i$. This captures the notion that different individuals will have different wealth endowments and will face different constraints in their decision to become owner-occupiers. Stated differently, some individuals will be able to obtain less strenuous financing conditions, such as lower LTV ratios and lower interest rates, resulting in lower mortgage payments. Our fixed-effects empirical strategy will deal with these sources of unobserved heterogeneity. However, mortgage payments will also vary within individuals over time as they reimburse their loan, reduce their LTV ratios and eventually refinance their mortgage at more advantageous conditions. We will exploit this source of variation to test some of our model predictions.

The second block of our model relates to an individual's occupation choice. In our set-up, workers have the choice between two occupations, which determine their income. Dependent workers receive income $Y_{w}$ and entrepreneurs receive income $Y_{e}$. We assume that the income of an entrepreneur is a mean-preserving spread of an employee's income:

$$
\mathbb{E} Y_{e}=\mathbb{E} Y_{w}=\bar{Y} \text { and } \sigma_{e}^{2}>\sigma_{w}^{2}
$$

where $\sigma_{e}^{2}$ and $\sigma_{w}^{2}$ indicate the variance of entrepreneurial and non-entrepreneurial income, respectively.

In this setting, the average income for entrepreneurs is the same as for dependent workers, but has a greater variability. This assumption is consistent with the literature on entrepreneurial labor choice: Hamilton (2000) shows that entrepreneurs earn on average the same or less than comparable dependent workers, though their income volatility is significantly larger. ${ }^{6}$ Furthermore, evidence in Blanchflower and Oswald (1992), Evans and Leighton (1989), and Hurst and Pugsley (2011) suggests that non-pecuniary benefits (e.g. being one's own boss or having flexible working hours) play a first-order role in the business formation decision. Thus, we assume that agents get a positive utility shift $\alpha_{i} \geq 0$ when they decide to become entrepreneurs, and we allow this 'taste for entrepreneurship' to vary across individuals as indicated by the subscript $i .^{7}$ The total utility for agent $i$ can be characterized as follows:

$$
\begin{array}{ll}
U(C, H) & \text { if agent } i \text { is a worker, } \\
\alpha_{i}+U(C, H) & \text { if agent } i \text { is an entrepreneur. }
\end{array}
$$

\footnotetext{
${ }^{5}$ Allowing for the costly adjustment of consumption commitments (owner-occupied housing) would create situations, in which big gambles are preferred to small gambles, as in Chetty and Szeidl (2007) and Shore and Sinai (2010). We abstract from this possibility in the current paper.

${ }^{6}$ In our empirical analysis, we replicate this fact. We return to this issue in Section 5.

${ }^{7}$ This setting is different from a model à la Lucas (1978) where individuals' entrepreneurial choices are driven by 'business acumen', i.e. the ability to generate extra gains by running a business.
} 
We further assume that the quantity of housing consumed by homeowners $(\bar{H})$ is equal to the quantity of housing that renters who have a realized income $\bar{Y}$ would choose. This second assumption helps us to focus on the consequences of housing commitments for occupation choice, rather than study how occupation might change housing consumption on the intensive margin (as in Davidoff, 2006).

We assume that individuals maximize their indirect utilities, which depend on income $Y$ and are denoted by $V(Y)$. This formulation has the advantage of highlighting the unique source of uncertainty in the model, i.e. the random variable $Y$. Before the uncertainty is resolved and a value for $Y$ is drawn, individuals have to choose whether to be owners or renters, and workers or entrepreneurs. To do so, they compare the expected utilities of the different tenure choices and employment possibilities.

To facilitate these comparisons, we use a second-order approximation of the expected indirect utilities:

$$
\mathbb{E} V(Y)=V(\bar{Y})+\frac{\sigma^{2}}{2} V^{\prime \prime}(\bar{Y})
$$

This approximation reduces the problem to a mean-variance analysis. ${ }^{8}$ The approximation is exact when $V^{\prime \prime \prime}(Y)=0$, i.e., when the utility function is quadratic. The second derivative $V^{\prime \prime}(\bar{Y})$ represents the curvature of the utility function and has an important role in the analysis since it is linked to the degree of risk aversion.

\subsection{The entrepreneurship decision}

We are interested in studying individuals' employment decisions conditional on their tenure status. Lemma 1 states the condition under which an individual prefers entrepreneurship to dependent employment.

Lemma 1. Agent $i$ is an entrepreneur if:

$$
\alpha_{i}>\frac{\sigma_{e}^{2}-\sigma_{w}^{2}}{2}\left(-V^{\prime \prime}(\bar{Y})\right)
$$

Proof. See Analytical Appendix.

The formula of Lemma 1 can be restated in terms of costs vs. benefits: the benefit of entrepreneurship is given by the utility boost $\alpha_{i}$, whereas its cost is given by the excess income variance $\left(\sigma_{e}^{2}-\sigma_{w}^{2}\right)$ multiplied by the curvature of the utility function $-V^{\prime \prime}(\bar{Y})$, i.e. the extent of risk aversion.

In terms of the subsequent empirical analysis, Lemma 1 highlights the importance of controlling for unobserved, time-invariant individual characteristics, such as $\alpha_{i}$ : individuals have different innate preferences for entrepreneurship and it is necessary to control for these before analyzing the relation between homeownership and entrepreneurship. Following this intuition, in our empirical strategy we adopt a fixed-effects strategy effectively partialling-out time-invariant unobservables. Our fixed-effects coefficient can be represented as follows:

$$
\text { Fixed-effects coeff. }=\operatorname{Prob}(\text { Entrep } \mid \text { Own })_{i=\bar{i}}-\operatorname{Prob}(\text { Entrep } \mid \text { Rent })_{i=\bar{i}}
$$

averaged across all $i$ 's. This formula shows that, according to our stylized model, the fixed-effects coefficient is different from zero when the curvature of the indirect utility function for owners, $V_{O}^{\prime \prime}(\bar{Y})$, is

\footnotetext{
${ }^{8}$ The first derivative of the indirect utility function $V^{\prime}(Y)$ disappears from this expression since it is evaluated at the point where $\bar{Y}=Y$ so that $\mathbb{E}(\bar{Y}-Y)=0$.
} 
different from the curvature of the indirect utility function for renters, $V_{R}^{\prime \prime}(\bar{Y})$. The magnitude of $V_{O}^{\prime \prime}(\bar{Y})$ in turn depends on housing costs $m_{i}$, as the following Lemma explains.

Lemma 2. For homeowners, the second derivative of the indirect utility function $V_{O}^{\prime \prime}$ depends negatively on the cost of housing:

$$
\frac{d V_{O}^{\prime \prime}(\bar{Y})}{d m_{i}}<0
$$

Proof. See Analytical Appendix.

Lemma 2 is a direct consequence of the prudence assumption. Intuitively, a greater commitment in terms of regular mortgage payments increases consumption variability: income variations are translated one-to-one to consumption; the same income change means a greater relative consumption change when mortgage payments are higher. This in turn increases an individual's effective risk aversion. Note that in our fixed-effects regression analysis we will be exploiting within-individual variation in leverage and mortgage payments. So effectively the derivative in Lemma 2 refers to variation in the cost of housing for the same individual over time.

We next formulate the three main propositions stemming from the model.

Proposition 1. If house ownership costs $\left(m_{i}\right)$ are on average at or close to market rents ( $r$ ), conditional on individual fixed effects, the link between homeownership and entrepreneurship is negative.

Proof. See Analytical Appendix.

Given the empirical variation that we exploit in our analysis, Proposition 1 can be interpreted as follows: if upon becoming homeowner, an individual's cost of borrowing is the same as or close to the market rent she would pay on the same property (i.e., the individual has large mortgage payments), then the sign of a fixed-effects regression of entrepreneurship on homeownership is negative. In particular, when $m_{i}=r$, there is no advantage to owning a house: the cost of owning is the same as the cost of renting, but owners cannot adjust their housing consumption. This implies that homeowners will shy away from risky occupations, such as entrepreneurship. By a continuity argument, the outcome of a comparison between owning and renting does not change when $m_{i}<r$, but 'close' - where 'close' is defined in more detail in the Analytical Appendix A.3. Note however that the sign of the fixed-effects regression is not fully determined if $m_{i}$ is allowed to take low values. This is because a low $m_{i}$ increases disposable income, although owners are still unable to adjust housing consumption. The Analytical Appendix and the discussion that follows below clarify this point.

Proposition 2 spells out the consequences of Lemmas 1 and 2 for estimating the effect of mortgage debt on entrepreneurship.

Proposition 2. The link between homeownership and entrepreneurship depends negatively on the extent of mortgage debt.

Proof. According to Lemma 2, an increase in $m_{i}$ lowers $V_{O}^{\prime \prime}(\bar{Y})$ for a given individual. According to Lemma 1, a lower $V_{O}^{\prime \prime}(\bar{Y})$ increases the threshold for individual $i$ to prefer entrepreneurship. This means Prob ( Entrep | Own $)_{i=\bar{i}}$ in equation (2) goes down, making the fixed-effects coefficient more negative.

It is informative to see what happens when $m_{i}$ takes its minimum possible value, namely zero. Empirically, this captures the situation where an individual has paid out the mortgage entirely. On the one hand, in such a situation disposable income is high and utility is in an area where its curvature $V_{O}^{\prime \prime}$ is low. On the other hand, housing consumption is fixed so it will still be the case that commitment 
increases risk aversion by raising the curvature of the utility function. This implies that the outcome and in turn the sign of the fixed-effects coefficient - when $m_{i} \rightarrow 0$ (i.e., for individuals who have fully repaid their mortgage) is ambiguous unless one is willing to make further assumptions. We discuss this issue further in the Appendix.

Our final proposition explores the effect of variations in entrepreneurial risk, $\sigma_{e}^{2}$.

Proposition 3. The negative link between housing mortgage debt and entrepreneurship is greater in sectors where profits have higher variance.

Proof. Lemma 1 shows that the threshold for choosing an entrepreneurial occupation depends positively on $\sigma_{e}^{2}$ : a higher variability of entrepreneurial income makes entrepreneurship more risky and therefore less favorable. This negative effect is interacted with the curvature of the indirect utility function, $-V_{O}^{\prime \prime}(\bar{Y})$, which is higher when mortgage debt is higher.

The structure of this section has been organized in such a way that it sets the ground for the empirical analysis, where we explore employment choice conditional on tenure, while accounting for individual unobserved heterogeneity with respect to $\alpha_{i}$ and $m_{i}$ using a fixed-effects approach. We have not discussed the result of a regression similar to the one illustrated in equation (2), but without individual fixed-effects, i.e. without controlling for unobservables. The model is not informative in such a setting as the predicted sign of this OLS-type regression depends (among other things) on the distribution of $\alpha_{i}$ across individuals and on how this co-varies with the housing ownership costs $m_{i}$.

Finally, we note that we have not closed the model by providing a discussion on individuals' tenure decisions conditional on their occupation. Given our one-period framework, individuals' occupation and tenure choices are taken simultaneously in ways that depend on all the model parameters, i.e. an individual's idiosyncratic 'taste for entrepreneurship', the homeownership costs, the riskiness of entrepreneurial income relative to dependent employment, and the exact shape of the utility function. A detailed discussion of these features is presented in the Analytical Appendix A.4, although these results do not add much content to the three predictions that we take to the data - where we investigate the link running from tenure choice to occupational choice. As stated in the Introduction, more individuals transit into leveraged homeownership - and at an earlier age - than into entrepreneurship. Thus, it seems natural to link homeownership to entrepreneurship in this order.

\section{Data}

The BHPS is a long panel dataset covering the period between 1991 and 2008 and providing detailed information on households' tenure choices and characteristics, as well as on individuals' current occupations, job-history between interviews, personal characteristics, income and financial situation/perceptions. The first wave of the panel consists of approximately 5,500 households and more than 10,000 individuals living in the UK. One of the significant advantages of the BHPS is that it is quite successful in following the same individuals over time, even when they move residence or form new households (e.g., the children of the original BHPS families or divorcees).

At the time of the interview (normally in September; in exceptional cases in subsequent months), respondents are asked to describe their current labor force status. If they are working, detailed information about their occupation is collected. Respondents are also asked whether their labor force status has changed since their last interview. If the answer is positive, a set of detailed questions is asked about all 
the occupational spells that occurred between the interview taking place and September of the previous year. ${ }^{9}$

The way in which the BHPS is structured makes it possible that some inconsistencies arise in the description of the same labor force spell provided by the same person in two different waves. Several authors have discussed the complicated task of reconstructing detailed monthly spells from the BHPS (Paull, 2002; Maré, 2006). We follow the principle that information recorded closest to the date of the beginning of the spell is the most accurate. A similar approach is used in Upward (1999) and Battu and Phimister (2008). We provide a detailed description of our procedure to assemble the data in the Data Appendix.

In order to identify the relation between homeownership and entrepreneurship, we need information about individuals' tenure choices with special attention to the timing of events. We first gather information about respondents' present tenure status. The possible categories are: homeowner with mortgage, homeowner without mortgage, private tenant, and social tenant. ${ }^{10}$ We then use the date in which respondents say they moved to their present address to identify the timing of changes in an individual's tenure status. If the respondent changed her tenure status from one wave to another and there is a moving date, we take this date as the transition date. Approximately $93 \%$ of the individuals have a moving date when making a transition into/out of homeownership. If the respondent changes her tenure status but there is no moving date, the transition date is imputed as the date of the current interview. ${ }^{11}$

Other controls - such as education level, age, marital status and number of children - are treated as constant between one wave and the other. Changes are assumed to take place at the date of the annual interview.

In terms of sampling, we begin with an initial set including all respondents who gave a full interview in Wave 1 or one of the following waves. We then follow them until they exit the survey for the first time, even if they come back at a later stage. This restriction is imposed because we need to be able to construct a continuous account of an individual's labor force status for every month combined with precise information on her tenure status. It is not possible to reconstruct in-between labor market spells and tenure choices for people who skip an interview. In Wave 1 (1991) we have 9,892 individuals. In Wave 18 (2008) we have 6,309 individuals, of which 3,642 are from the initial sample interviewed in Wave 1. Observations decrease gradually, reflecting ageing and attrition in the original sample. On the other hand, children and spouses of original members join the dataset, partially counterbalancing the decreasing tendency.

In our analysis, we focus on heads of households in their prime working age (between 20 and 55) and consider only their employment spells (either as workers or self-employed). By focusing on these individuals, we limit the importance of issues related to labor market participation - since in our data 'head of household' refers to the individual within the household who manages the financial aspects and is considered the main economic actor. Moreover, we restrict our attention to the choice between entrepreneurship and dependent employment. As we show in the robustness checks, including unemployment and other labor market status spells in our analysis does not alter our results.

We only focus on individuals living in England, because for this group we can match precise infor-

\footnotetext{
${ }^{9}$ In their first wave, respondents are asked whether their labor force status has changed since the 1st of September of the previous year, and - if so - precise information about their job history is collected. In this way, the BHPS covers every month of the labor history of the respondents since one year before their first interview to present.

${ }^{10}$ There are other rare options, such as living in an accommodation paid by the employer, which we do not consider in our analysis. This exclusion does not affect our findings.

${ }^{11}$ It is possible to change tenure status without changing address. In the UK, for instance, the 'right-to-buy' programme allows social tenants to buy their house or flat from the local authority (van Ham et al., 2010). Similarly, individuals could buy from their current private landlord. However, this does not seem widespread.
} 
mation about prevailing local housing market conditions. To merge in such information, we use the restricted-access version of the BHPS that provides an identifier for the Local Authority (LA) where the individual lives. footnoteLAs are local constituencies empowered to exercise planning functions, and can be thought of as self-contained housing markets from a regulatory point of view. England consists of 354 LAs. We use LA identifiers to merge LA-specific LTV data from the Survey of Mortgage Lenders (SML) provided by the Council of Mortgage Lenders (CML) to the BHPS. ${ }^{12}$ Additionally, we match LAspecific house price data coming from the SML (until 1995) and from the Land Registry (from 1995). ${ }^{13}$ Finally, our proxy measures for the elasticity of local housing supply - i.e. the LA-specific percentage of developed land and the LA-level refusal rate - are derived from Hilber and Vermeulen $(2012)^{14}$

We will exploit this information when investigating the mechanisms that explain our findings. However, our main results are virtually identical when we include individuals living in Wales, Scotland and Northern Ireland.

After implementing these restrictions, our sample includes approximately 360,000 observations (i.e., individual monthly spells) and 5,200 individuals. The richness and detail of the dataset is a novel element of our analysis. Most panel-type studies of entrepreneurship (Hurst and Lusardi, 2004; Disney and Gathergood, 2009) rely on annual observations. This frequency does not allow pinning down the precise timing of individuals' transitions into homeownership and entrepreneurial jobs, which is crucial when trying to identify the relation running from changes in housing tenure to transitions into entrepreneurial occupations.

\section{$5 \quad$ Descriptive statistics}

The first set of descriptive statistics for the BHPS monthly spell dataset is presented in Table 1. The first row of Panel A presents descriptive statistics for our proxy for entrepreneurship, i.e. self-employment with dependent workers, indicating that $4.7 \%$ of employment spells are classified as entrepreneurial. This figure is substantially lower than the one obtained considering other proxies used in the literature, for example 'all self-employed' - at $14.4 \%$ in our sample - or 'self-employed in managerial and professional occupation' - at $7 \%{ }^{15}$ In our main analysis, we focus on self-employed with dependent workers since we believe this definition better captures entrepreneurship. However, we present robustness checks using alternative definitions in Section 5.3.

Panel A also shows that the fraction of homeowners in the monthly spell data is $81 \%^{16}$. Around $71 \%$ of the observations involve homeownership with a mortgage, whereas $9.6 \%$ refer to owners with no mortgage. For the former, the LTV on the mortgage is on average $48.5 \%$. This information is timevarying and is calculated as the ratio between the outstanding amount of mortgage debt owed by the individuals and the self-assessed house value. The proxy varies over time because of amortization and refinancing, as well as changes in the value of the asset. On average, individuals report housing values

\footnotetext{
${ }^{12}$ The SML has a broad coverage of UK mortgage lenders in addition to building societies, and collects a wide range of mortgage-related information such as the amount of gross interest rates charged, whether the rate is fixed or variable, various repayment methods, purchase price and mortgage amount.

${ }^{13}$ Specifically, we use annual LA-level mix-adjusted house prices - see Hilber and Vermeulen (2012) for details of the computation - and merged this data to our monthly BHPS data at a yearly frequency.

${ }^{14}$ See Hilber and Vermeulen (2012) for further details on the computation of these variables and the underlying original sources.

${ }^{15}$ The percentage of self-employment in our sample is consistent with Blanchflower and Shadforth (2007), who use several years of quarterly data from the Labour Force Survey to document that self-employment in the UK has stayed between $12 \%$ and $15 \%$ in the 1991 to 2007 period.

${ }^{16}$ This figure is close to the one reported by Battu and Phimister (2008) (at 79\%) who use the same data to study the effect of homeownership on unemployment duration.
} 
of approximately $£ 120,000$, though this figure is associated with a large standard deviation of $£ 110,000$. Monthly mortgage payments are around $£ 380$.

Panel B tabulates descriptive statistics for background characteristics. These show that the average individual is 39.4 years old; males represent $79 \%$ of observations; $75 \%$ of the spells refer to coupled individuals, and $46 \%$ to individuals with children under the age of 16. Finally, individual and household total incomes in the year prior to the survey stand at $£ 20,990$ and $£ 31,728$, respectively.

In Table 2, we present more descriptive statistics about individuals' incomes. A comparison of the first and second row shows that entrepreneurs earn a slightly larger average income than dependent workers, but the median income for these two groups is very close at $£ 18,500$ and $£ 18,322$, respectively. The last two columns show that entrepreneurship is a risker choice than dependent employment. The overall standard deviation of entrepreneurs' incomes is 2.3 times larger than the figure for dependent workers (respectively at $£ 33,608$ and $£ 14,528$ ). The same holds true if we look at the standard deviation of incomes within-individuals over time. This evidence is consistent with Hamilton (2000) and supports our modeling assumptions.

In Table 3, we display the incidence of transitions into and out of homeownership and in and out of entrepreneurship since this information is relevant for our fixed-effects estimation. Around $18 \%$ of all individuals make at least one homeownership transition (for example 'rent' to 'own') and $5.4 \%$ at least two transitions (e.g. 'rent' to 'own', to 'rent' again). The figures also show that more people transit into homeownership than out of it, and that more transitions involve mortgages than outright ownership. A substantial fraction of individuals with mortgages transits into outright homeownership, though some of them - as well as some outright owners - revert back to renting. We also find that $5.9 \%$ of the spells involve one transition into or out of entrepreneurship, and 3.3\% involve more than one entrepreneurial transition. Finally, the fraction of workers with at least one tenure transition and one entrepreneurial transition is approximately $3 \%$, increasing to more than $4 \%$ when considering transitions in and out of homeownership with a mortgage.

We also investigate the characteristics of individuals who transit into and out of homeownership and entrepreneurship. Our findings are presented in Table 4. Relative to those who become homeowners without a mortgage, individuals who use a loan to purchase their property are younger (30.4 vs. 37.4 years), are less likely to have children ( $62.3 \%$ vs. $67.7 \%)$, and are less affluent (£13,547 vs. £16,105). Individuals who become entrepreneurs with dependent workers are older (at 35.4) than individuals transiting into homeownership with a mortgage, but younger than outright owners. This suggests a time-line where individuals first purchase a property with a mortgage, then decide their occupation, and eventually pay off the mortgage. This is consistent with our modeling framework and empirical analysis, where we focus on the effect of tenure decisions on occupational choices.

We also find that individuals who become entrepreneurs are better off in terms of prior income and are more likely the be in a couple and have children. We do not detect any clear pattern in terms of age, family arrangements and income for people transiting out of homeownership and entrepreneurship. This suggests that these movements cannot be easily explained by demographic factors and that other individual specific considerations might be taking place in ways that simultaneously affect the tenure status and entrepreneurship. We will return to these issues below. 


\section{Main findings}

\subsection{Testing Proposition 1: The negative link between homeownership and entrepreneurship}

Proposition 1 from our model asserts that, if ownership costs $\left(m_{i}\right)$ are on average at or close to market rents $(r)$, conditional on individual fixed effects, the relation between homeownership and entrepreneurship is negative. The condition that on average $m_{i}$ is at or close to $r$ arguably applies to home-buyers in our regression sample: we find that, on average, for individuals who become homeowners with a mortgage, rents prior to transition into owner-occupation are between $10 \%$ cheaper and $8 \%$ more expensive than initial mortgage costs depending on the exact observational window around transition into homeownership that we use to calculate this figure. This result should only be taken as indicative since it is obtained from regressions that control for individual time-fixed unobservables and time-varying characteristics, but do not control for housing characteristics. Nevertheless, this finding suggests that on average initial mortgage costs are not dissimilar from rents and implies that in our sample of British household heads aged between 20 and 55 the relation between homeownership and entrepreneurship can be expected to be negative.

Our first set of regression results is presented in Table 5, where we report estimates obtained from fitting the following linear probability model:

$$
\text { Entrep }_{i l t}=\eta_{i}+\beta \text { own }_{i l t}+X_{i l t} \gamma+\phi_{l}+\omega_{t}+\varepsilon_{i l t}
$$

where the dependent variable Entrep $_{i l t}$ is our (binary) proxy for an entrepreneurial job, and the explanatory variable of interest is an individual's housing tenure status own $_{i l t}$. The subscript ilt identifies individual $i$ living in location $l$ at time $t . X_{i l t}$ is the set of time-varying controls discussed above and described in Table 1, while $\phi_{l}$ and $\omega_{t}$ represent location and time fixed effects. Location (LA) fixed effects $\left(\phi_{l}\right)$ include persistent geographical disparities in labor and housing markets and differences in local political and institutional factors, whereas the time fixed effects $\left(\omega_{t}\right)$ capture unobserved factors that are specific to the year and/or month of interview. Finally, $\eta_{i}$ captures unobserved individual factors - such as taste for entrepreneurship ( $\alpha_{i}$ in our model) and persistent wealth (related to $\left.m_{i}\right)$ - which may simultaneously determine occupational choice and tenure status. The error-term $\varepsilon_{i l t}$ is assumed to be uncorrelated with all the right-hand side variables, although we allow for correlation in residual shocks across individuals within locations and cluster standard errors at the LA level. ${ }^{17}$

Columns (1) and (2) of Table 1 present simple cross-sectional (OLS) estimates of Equation (3). In Column (1), we append year-of-interview and month-of-interview effects, as well as dummies for the sector of employment (using the SIC92 classification at 1-digit level), while in Column (2) we further include the controls detailed in Table 1, as well as LA dummies. The two specifications indicate a positive and significant association between homeownership and entrepreneurship. Although the estimated coefficients are attenuated when adding individual controls and LA effects, the estimates remain sizable and highly significant.

However, cross-sectional regressions cannot control for individuals' unobservables $-\eta_{i}$ in Equation 3. In order to partial out these unobserved factors, we estimate various fixed-effects models, which are

\footnotetext{
${ }^{17}$ We also experimented with the inclusion of Travel-To-Work Area (TTWA) effects and with clustering at this level of aggregation and came to similar conclusions. TTWAs are 243 functional areas drawn by the Office for National Statistics to identify self-contained local labor markets. We also experimented with two-way clustering at the individual and LA level, which also did not affect the statistical significance of our findings.
} 
presented in Columns (3) to (7). In stark contrast to the OLS regressions, in Column (3) we find that once we control for individual fixed effects homeownership is negatively associated with entrepreneurship. This is consistent with the first prediction of our model (Proposition 1).

To assess the robustness of our findings to time-varying individual and household characteristics and local unobservable factors, in Column (4) we add the control variables detailed in Table 1, as well as LA dummies. The set of controls includes both individual and household total income in the year prior to the survey (in logs). Conditional on individual fixed effects, these variables capture changes in the financial situation of an individual and her household with respect to the previous year, and therefore act as good proxies for changes in an individual's wealth. Finally, in Column (5) we retain the set of controls included in Column (4), but drop LA dummies since only $30 \%$ of the individuals change their place of residence over the period of our analysis (for immobile individuals local effects are absorbed by the individual fixed effects).

The results in Columns (4) and (5) provide further evidence in favor of Proposition 1: there is a significant negative association between homeownership and the probability of being an entrepreneur. ${ }^{18}$ The estimates represent a sizable relation: given the mean probability of being an entrepreneur, becoming a homeowner is associated with a reduction in the probability of starting-up a business by $20-25 \%$.

The results presented so far suggest that, once we control for individual fixed effects, homeowners are less likely to become entrepreneurs. However, as discussed above, some individuals transit into homeownership and others transit out of it. Hence, part of our results might be driven by individuals who sell their property in order to extract equity from their home, gather enough liquidity to undo underlying credit constraints and become entrepreneurs. To directly explore the relevance of this channel, in Columns (6) and (7) of Table 1, we focus on individuals' spells that correspond to transitions into and out of homeownership, respectively. In Column (6), we follow individuals who start off as renters and then become homeowners till eventually switching back to renting (plus individuals who start off as owners and stay as such throughout the period). In Column (7), by contrast, we track individuals who finish as renters after having been homeowners (plus individuals who start off as renters and do not change tenure throughout the sample period), and exclude any renting spells that took place before homeownership. Our findings suggest that the estimated negative impact of homeownership only comes from individuals who become homeowners. The estimated effect is larger and more precisely estimated than before. Conversely, the link between tenure status and entrepreneurship for individuals switching out of homeownership is estimated to be small and insignificant. Once again, this pattern is consistent with Proposition 1.

One concern with our fixed-effects estimation is that it partials out individual, household, location and time fixed unobservables, but cannot control for time-varying unobserved factors. Adding timevarying individual and household level controls mitigates this problem. In particular, we can control for income, number of children and marital status, which have been shown to be strongly associated with homeownership and entrepreneurship (Linneman and Wachter, 1989; Hilber, 2007; Evans and Leighton, 1989). Moreover, other plausible time-varying unobserved factors - such as 'winning the lottery' or receiving an inheritance - would bias our results towards finding a positive link between homeownership and entrepreneurship, since wealth is positively associated to both purchasing a home and becoming an entrepreneur (Blanchflower and Oswald, 1998). Nevertheless, as these are serious concerns, in Section 6.3 we subject our findings to a number of robustness checks.

\footnotetext{
${ }^{18}$ Excluding potentially endogenous controls, such as sector of occupation or individual and household income in the year prior to the survey, does not affect our findings.
} 


\subsection{Dissecting the fixed-effects results: Timing and dynamics}

The fixed-effects regressions discussed above are silent on whether the link between homeownership and entrepreneurship represents an instantaneous and permanent effect, or whether this link dissipates over time. We present evidence on this point in Table 6 . Recall that for approximately $7 \%$ of the individuals we cannot properly identify the date at which they made a transition into/out of homeownership (and thus we imputed it using the timing of their interview). In Column (1) we replicate our analysis excluding these individuals from the sample. The estimates we obtain are now larger and more precisely estimated than before. In the remaining analysis in this section, we focus on people with non-imputed transition dates.

In Column (2), we start our analysis of dynamic effects by including in the empirical model a count of the monthly duration since the individual became a homeowner. This variable displays a positive, but very small and insignificant coefficient implying that the relation between homeownership and entrepreneurship never crosses the zero line and turns positive.

In Column (3) we add to our specification both a linear and a quadratic term in the monthly duration. We now find that the linear term becomes positive and significant (0.016; s.e. 0.008), while the coefficient on the squared duration is negative and borderline significant (-0.005; s.e. 0.003). This implies an inverted U-shaped relationship between the time since becoming a homeowner and the probability of becoming an entrepreneur. We present this graphically in the top Panel A of Figure 1. These results imply that - on impact - the link between homeownership and entrepreneurship is as large as -0.018, but that as time goes by, this negative effect becomes less quantitatively meaningful. It takes 4 years (48 months) for the effect to become statistically insignificant at the $5 \%$ level. However, the effect of homeownership never turns positive, even when considering fairly long time horizons, e.g. after 10 years (120 months). Moreover, the impact of the monthly duration hits a maximum at 160 months (approximately 13.3 years), where the overall link between homeownership and entrepreneurship remains negative at -0.005 .

Since the dynamics of the relation between homeownership and entrepreneurship are an important issue that could assist the interpretation of our results, we further investigate this point using a complementary approach. Our results are presented graphically in Panel B of Figure 1. The graph plots coefficients and confidence intervals obtained by running 18 separate regressions (plus our benchmark result) where we consider the link between current homeownership and lags and leads of entrepreneurship. On the positive axis of the graph, we check whether present homeownership is related to the probability of being an entrepreneur with dependent workers between 3 months and 36 months after becoming a homeowner. The negative side of the axis investigates whether current homeownership is related to entrepreneurship between 3 months and 36 months before actually purchasing a home. ${ }^{19}$

Although this approach is very flexible in analyzing anticipation and long-lasting effects of homeownership, one drawback is that - by using leads and lags - it significantly reduces sample size. This loss of observations is particularly severe when moving further into the future or into the past. For example, when considering 18-months leads/lags, we are left with approximately 310,000 observations over 4,300 individuals (out of the original 5,193 workers), further dropping to around 270,000 for 3700 individuals when focusing on 36-months leads/lags.

Nevertheless, the main insights from this analysis are informative. On the one hand, we find that the negative link between homeownership and entrepreneurship is stronger on impact and then slowly fades

\footnotetext{
${ }^{19}$ By looking at the relation between current homeownership and leads and lags of entrepreneurship we fix the controls at the time of transition into homeownership. We experimented with an alternative approach analyzing the effect of leads and lags of homeownership on current entrepreneurship, which centers the controls at the time of the employment transition. This second method gave nearly identical results.
} 
away. The effect becomes insignificant 18 to 24 months after transition into homeownership, and then flattens out without ever becoming positive. On the other hand, we find that anticipation effects are already evident and significant 12 to 18 months before entry into homeownership. This time difference can be interpreted as the lag between the decision to buy a house and its actual purchase, and suggests that the purchase decision affects individuals' behavior in relation to entrepreneurship even if the house has not been actually bought. This pattern is consistent with the logic highlighted by our model, where homeownership crowds out entrepreneurship because of commitment considerations. A similar pattern has been documented by Engelhardt (1996) who studies the anticipated effects of housing commitments on consumption decisions.

\subsection{Robustness checks}

Our robustness checks are reported in Appendix Table 1. To begin with, we investigate whether the results differ when we use alternative proxies to identify entrepreneurs. In Column (1) we consider all selfemployed individuals and still find a negative association between homeownership and entrepreneurship. In Column (2) we use the socio-economic classification of jobs provided by the BHPS (SOC2000 at the 1-digit level) to identify self-employed who are "managers and senior officials", work in "professional occupations", or identify themselves as "associate professional and technical occupations". We label this group 'entrepreneurs: manager'. Even when using this category, we find a negative and significant association between homeownership and entrepreneurship.

Next, in Column (3) we check that our results are not driven by individuals' unemployment experiences by including in our data unemployment spells - in addition to dependent employment and self-employment spells. This does not change our findings. Similarly, our results are not driven by short spells of employment used as stop-gap jobs. When we exclude self-employment and employment experiences that last less than 12 months, this does not alter our results.

Column (4) and (5) assess the robustness of our results along geographical dimensions. First, we investigate whether the results may be driven by the geographical mobility of workers upon becoming homeowners. Individuals who choose to purchase a house might leave urban areas and this might affect their chances of becoming entrepreneurs. Previous evidence shows that more properties are rented as opposed to owner-occupied in riskier urban centers (Hilber, 2005), and that more entrepreneurs cluster into denser cities because of urbanization and localization economies (Glaeser, 2009; Glaeser and Kerr, 2010). To address this concern, in Column (4) we exclude from our analysis individuals who make either urban-to-rural or rural-to-urban residential moves, and only consider immobile workers (approximately $87 \%$ of the observations). Despite this reduction in sample size, we still find a negative association between homeownership and entrepreneurship (-0.010), significant at the $10 \%$ level. One related consideration is that our results may be driven by London, where many entrepreneurial activities concentrate and more households rent. In Column (5) we exclude individuals who live in London (approximately $12 \%$ of all observations) and find that our results are virtually unchanged. ${ }^{20}$

In the remaining three columns of Appendix Table 1, we check whether our results only stem from a handful of sectors or whether they are economy-wide. In Column (6) we use the SIC92 industrial classification at 1-digit level to exclude the following sectors: agriculture; fishing and forestry; electricity, gas and

\footnotetext{
${ }^{20}$ We also investigate whether our results may be different for urban and rural areas. Our point estimates suggest that homeownership is negatively associated with entrepreneurship across the board, although the results are statistically significant only for urban areas. Our estimates for rural locations are larger in magnitude despite being statistically insignificant. This is perhaps unsurprising as this breakdown leaves us with $79 \%$ of the observations in urban areas and only $21 \%$ in rural ones.
} 
water; public administration; private households with employees; and workers of international organizations/bodies. This approach follows Glaeser (2009) and Faggio and Silva (2011) who use self-employment data to study the spatial distribution of entrepreneurial activities in the US and UK, respectively. When doing this, we still find that homeownership is negatively associated with the chances of becoming an entrepreneur. Finally, in the last two columns, we consider services only (Column 8) or manufacturing only (Column 9). Our conclusions remain valid when we focus on services. However, the point estimates are small and not significant when we only consider manufacturing. This result may be due to the fact that only approximately $25 \%$ of the observations come from individuals working in manufacturing. Moreover, the share of entrepreneurs with dependent workers is significantly smaller for this sector, at only $2.3 \%$. Nevertheless, the coefficient in Column (8) still implies an economically meaningful negative link between homeownership and entrepreneurship: becoming a homeowner reduces the chances of entrepreneurship by $12.5 \%$.

\section{Additional findings: Exploring the theoretical mechanisms}

Our results so far lend empirical support to Proposition 1. In this section, we test Propositions 2 and 3.

\subsection{Testing Proposition 2: The Role of mortgage debt}

We test Proposition 2 by adding to our core specification a variable that identifies whether an individual is a homeowner with a mortgage. The results are reported in Column (1) of Table 7. We find little evidence that homeownership per se is negatively associated with entrepreneurship. However, we find strong evidence that individuals who purchase a house with a mortgage are significantly less likely to become entrepreneurs. The implied economic magnitude of this association is economically highly meaningful: homeowners with a mortgage are approximately $30 \%$ less likely to start a business than renters.

Next, we refine our analysis of the role of mortgage financing by considering a time-varying measure of the LTV ratio as a proxy for the salience of mortgage debt. Specifically, we use time-varying data on the outstanding amount of mortgage debt owed by the individuals coupled with self-assessed house values, to construct a measure of the LTV ratio of the outstanding mortgage loan. This is likely to be a noisy proxy for the actual LTV because the house value is self-assessed. To address this issue, we use an IV approach that exploits time-varying information on local LTV ratios at the place of residence. ${ }^{21}$

Our results are reported in Columns (2) to (4) of Table 7. In Column (2) we include our proxy for the LTV alongside an indicator for whether an individual owns the property. Our results show that conditional on the LTV ratio, homeownership is no longer negatively and significantly associated with entrepreneurship - its effect is estimated to be precisely zero. As for the LTV ratio, this enters our specification with a negative and sizable effect, significant at the $1 \%$ level. The point estimate implies that a one standard deviation increase in the LTV is associated with a reduction in the probability of being an entrepreneur by about $8.3 \%$. In Column (3) we replace the homeownership dummy with a variable measuring the self-assessed value of the house. While the latter does not enter our regression significantly, we still find that the LTV on the mortgage is strongly and negatively associated with the probability of becoming an entrepreneur.

\footnotetext{
${ }^{21}$ We experimented with a set of alternative LTV proxies that all gave similar results. For example, we used information on the initial house price paid by individuals in combination with changes in local house prices to compute a time-varying measure for the value of the home, and thereby an LTV ratio.
} 
One concern with the LTV-proxy is that it may measure the actual LTV on the outstanding mortgage with noise. If this was the case our estimates would be biased towards zero. Furthermore, the LTV at which an individual borrows as well as the LTV on the outstanding mortgage may be endogenous and driven by time-varying individual unobservables. ${ }^{22}$ This is because, in the UK context, individuals have some discretion about their initial LTV as well as about the LTV on the outstanding amount of mortgage at later stages because of refinancing decisions.

To address this concern, we devise an IV strategy that exploits information on the LTV of newly originated mortgages in the LA of an individual's residence obtained from the SML. Specifically, we construct an instrument which is set to zero before an individual becomes a homeowner and equal to the time-varying local LTV in the LA of an individual's residence thereafter. The aim of this variable is to predict the exogenous part of the initial LTV at which an individual borrows and the subsequent LTV on the outstanding mortgage, exploiting the intuition that most of the mortgage financing conditions are dictated by the local housing market and banking conditions (see Muelbauer, 2002). We further control for self-assessed house values and local house prices to account for the effect of local economic cycles. ${ }^{23}$

Our fixed-effects IV results are reported in Column (4), with first-stage results tabulated at the bottom of the table. The first stage statistics indicate that there is a strong and positive link between an individual's LTV and local prevailing lending conditions. The second stage results are in line with the fixed-effects results presented in Column (3) and show that the LTV ratio of the outstanding mortgage is significantly negatively associated with entrepreneurship. The estimated coefficient is slightly larger than the corresponding coefficient in Column (3), where we do not use an IV approach, although the difference is not statistically significant. This suggests that measurement error - biasing our results towards zero - might be a more serious concern than endogeneity.

To further assess the validity of our results, we perform a number of additional robustness checks. To begin with, we run specifications controlling for local house prices - on top of the self-assessed value of the house. Results are reported in Column (1) of Appendix Table 2. Our previous conclusions are unaltered. We also include in our specification the monthly duration in homeownership to avoid attributing some of the effects of variation in time to changes in the LTV. Although the correlation between tenure duration and LTV is negatively signed as expected, it is not particularly strong at -0.483 . In any case, the inclusion of this additional control does not alter our results in a meaningful way.

Finally, we experiment using the (log of) monthly mortgage payments as an alternative proxy for the salience of mortgage finance. Results are reported in Columns (2) and (3) of Appendix Table 2. Column (2) tabulates simple fixed-effects estimates, while in Column (3) we instrument an individual's (log of) monthly mortgage payment using the (log of) local monthly payment as inferred from the SML data. The findings confirm our previous conclusions: there is a negative and significant association between the extent of mortgage debt and the probability of becoming an entrepreneur. The size of this relation is economically meaningful: a one standard deviation increase in monthly mortgage payments is associated with a $2.4-2.9 \%$ reduction in the likelihood of starting a business.

To sum up, these results are fully consistent with the second prediction of our model and with its underlying logic: when agents commit to mortgage payments, income variations get fully translated into consumption variations, instead of being smoothed out between consumption and housing. The larger the extent of mortgage debt, the smaller will be the individual's appetite for a risky occupational choice,

\footnotetext{
${ }^{22}$ Our fixed-effects strategy controls for an individual's time-fixed unobserved attitudes such as risk-tolerance or financial sophistication.

${ }^{23} \mathrm{~A}$ booming local economy is most likely associated with an increasing number of local entrepreneurs and a relaxation of local lending standards. This implies that, if local economic conditions were a significant source of bias and we properly controlled for these, our estimates should be even more negative.
} 
such as entrepreneurship. ${ }^{24}$ In the next subsection, we go on to provide more direct evidence supporting this proposition.

\subsection{Testing Proposition 3: The role of entrepreneurial risk}

The third prediction of our model states that the negative link between mortgage debt and entrepreneurship should be more pronounced for would-be entrepreneurs in riskier sectors. In order to test this proposition, we collect information contained in the Structural Business Statistics prepared by Eurostat. ${ }^{25}$ In particular, we assemble data on industry-level profits and investment (capital spending) per employee in the UK. Both variables are available at the NACE 2-digit sector level on an annual basis for the 1997 to 2007 period. This sectoral level aggregation can be mapped to the standard industry classification provided in the BHPS (SIC92), providing a sufficient level of detail by dividing the economy into 45 sectors.

Using this data, we calculate measures that capture sector-specific riskiness. To begin with, we compute the coefficient of variation of industry-level profits for the available period and split our dependent variable to consider entrepreneurs who work in risky sectors and entrepreneurs operating in non-risky sectors. We then run separate regressions with these two outcomes to investigate whether the negative link with mortgage debt is more pronounced and significant in industries characterized by more risk. ${ }^{26}$

Our results are displayed in Columns (5) and (6) of Table 7, where we split our dependent variable using the median of the distribution of the coefficient of variation of profits in the individual sample (at 0.1348). A comparison of the two columns reveals that the transition into entrepreneurship is only adversely affected by mortgage debt if the individuals work in risky sectors. To check the robustness of this result, we construct a second proxy capturing sector-specific risk. This is obtained by multiplying profit volatility by average investment per employee, and identifies sectors as risky when profits are highly volatile and sunk costs are significant. When we replicate the analysis of Columns (5) and (6) using this alternative measure, we find a similar pattern: the relation between mortgage debt and entrepreneurship is more negative and significant in risky sectors (at -0.014) than in non-risky sectors (at -0.008).

Finally, we check whether the variability in local house prices - as opposed to the variability in profits - can account for this pattern. Results are presented in Columns (4) and (5) of Appendix Table 2 , where we split the sample using the median of the coefficient of the variation of local house prices (at 0.8229). We find that the relation between mortgage debt and entrepreneurship remains negative and very similar in magnitude for individuals living in both high and low house price variation areas (though neither estimate is significant at conventional levels). The fact that the two point estimates are so close to each other is consistent with our simple model, in which house price considerations are not important since homeowners 'fully commit' to their housing decision (i.e. we impose immobility). The only risk homeowners consider is the one arising from occupational choice.

It is worth noting that the logic behind the negative relationship between mortgage debt and risky entrepreneurship is not dissimilar from the one underlying the negative relationship between leverage and risky investment - i.e. stocks - documented by Chetty and Szeidl (2010). Their results show that homeownership reduces stock investment, and that a $\$ 10,000$ dollar increase in mortgage debt

\footnotetext{
${ }^{24}$ Our results are also consistent with Davidoff (2006) who shows that individuals whose labor income co-varies strongly with housing values purchase relatively inexpensive homes or rent.

${ }^{25}$ This can be accessed at http://epp.eurostat.ec.europa.eu/portal/page/portal/european_business/ data/database, where more information on the data construction and availability is also provided.

${ }^{26}$ An alternative way of performing this test is to split our sample into individuals who work in risky sectors and those who do not. When we do this and run two regressions with two different samples - as opposed to two different dependent variables - we find similar results. Results are available from the authors upon request.
} 
(approximately a one standard deviation change) reduces the share of investments in stocks in liquid wealth by approximately $6 \%$ (holding total wealth constant). The sign and magnitude of this effect is fully consistent with our findings.

\subsection{Credit constraints as an alternative explanation? Some dispelling evi- dence}

The results discussed so far could be consistent with an alternative theory based on credit constraints: leveraged homeowners find it hard to obtain additional finance to start-up their business because they are already burdened with a substantial loan on their house. However, for this explanation to hold true, we should detect a positive relationship between house price increases and entry into entrepreneurship. This is because, as home values increase, LTV ratios are pushed down and housing becomes a collateral that can be used to borrow and relax credit constraints in the start-up decision. We provide some (dispelling) evidence on this alternative channel in Table 8.

To being with, we add local house prices (in logs) as a control in our main regression. As shown in Column (1), this has no effect on our main finding. More importantly, the dynamics of local house prices are not significantly related to the chances of becoming an entrepreneur.

Next, we calculate the cumulative percentage change in housing value using the variation in an individual's self-assessed house price valuation, and considering the variation between the time when she purchased the property and the current date. This gives a neat measure of any capital gains (or losses) accrued to an individual through homeownership, allowing us to explicitly test whether the equity position built into someone's real estate investment can be used as collateral to borrow and relax credit constraints in setting up a business. As shown in Column (2), this does not seem to be the case: the effect of the cumulative house price gains on the probability of becoming an entrepreneur is estimated to be small and insignificant. In contrast, the link between homeownership and entrepreneurship remains negative, significant and sizable at -0.014 (s.e. 0.006).

In Column (3) we address potential endogeneity issues with cumulative house price gains by following the approach used by Chetty and Szeidl (2010) and instrumenting the self-assessed cumulative house value changes using the variation in national house prices in interaction with proxies for the local housing supply elasticities. In particular, we create two instruments by computing the national cumulative house prices changes for the period relevant to each individual, and by multiplying these figures by the share of developed land in the LA and by the average LA refusal rate. ${ }^{27}$ The fixed-effects IV regressions tabulated in Column (3) display strong first-stages and confirm the results of Column (2): cumulative house price gains are not significantly associated with transition into entrepreneurship. Finally, in Column (4), we replace the measure that captures an individual's self-assessed housing capital gain with a proxy constructed using LA-average house prices and come to an identical conclusion.

To further investigate this issue, we also construct a proxy for the residual amount of cash accruing to an individual after mortgage payments. In order to obtain this measure, we consider mortgage payments in the month preceding the interview and subtract this quantity multiplied by twelve (assuming constant payments within the year) from the overall individual annual income. Controlling for this proxy does not change our headline finding. Moreover, we find that the coefficient on residual cash flows is positive, but very small and not significant at conventional levels. We also investigate whether considering some self-reported measures of individuals' perceptions about their current financial situation and financial expectations for the year ahead could confound our results. More precisely, we include in our analysis

\footnotetext{
${ }^{27}$ Using these instruments separately leads to very similar conclusions.
} 
answers to the following two questions: (i) "How well would you say you are managing financially these days? Living comfortably; going alright; just getting by; finding it difficult; finding it very difficult"; and (ii) "Looking ahead, how do you think you will be financially a year from now? Better than now; worse than now; same as now". Adding these controls to our specifications does not alter our key finding, and none of these proxies enters our regressions with a significant coefficient.

In the last two columns of Table 8, we investigate whether our results differ for individuals operating in capital intensive sectors. In Column (5) we interact the homeownership dummy with a variable measuring the sectoral average investment per employee obtained from Eurostat. We find no evidence that homeownership is more negatively associated with entrepreneurship in sectors with larger capital requirements. In Column (6) we follow Adelino et al. (2013) and investigate whether potential home equity gains have a differential impact in sectors with higher/lower capital requirements. We still find no evidence that cumulative house price gains are associated with entrepreneurship. Conversely, the relation between homeownership and business start-ups is negative and precisely estimated.

This set of tests suggests that credit constraints are not the main mechanism behind the novel finding documented in our paper. More generally, the estimates discussed in this section cast some doubt on the importance of credit constraints in business start-ups. While this result is at odds with the literature on the effects of wealth, income windfalls and financing issues on the decision to become an entrepreneur (see above), it is consistent with the work by Hurst and Lusardi (2004). The authors use US microlevel data from the PSID to show that the relationship between wealth and entrepreneurship is only significant at the very top of the wealth distribution. More to the point, they show - exactly as we do - that households living in areas which experience strong house price appreciation are not significantly more likely to start an entrepreneurial venture. ${ }^{28}$ Although it is impossible to conclusively establish what drives the differences between our micro-data evidence and studies that use more aggregate data (e.g. Black et al., 1996), we conjecture that some of these discrepancies might be explained by unobservables, which are better controlled for using micro-econometric techniques. Moreover, our results capture a short to medium-run trade-off between homeownership and entrepreneurship in the presence of commitment and mortgage debt. This cannot be easily detected using aggregated data that lack detailed information on a household's leverage.

\section{Conclusion}

In this paper we study the previously largely unexplored link between homeownership and entrepreneurship. Our main interest in this relationship rests on the notion that flourishing entrepreneurial activities can be associated to the creation of new businesses and an acceleration of innovation, both of which are conducive to higher economic growth. Previous analyses of the labor market effects of homeownership have focused on unemployment spells and duration, thus neglecting an important channel whereby housing might affect the country-wide economic performance.

We develop a model of occupational choice and housing tenure, where housing consumption is fixed for homeowners, but not for renters. Our model yields three core predictions: (i) conditional on individual characteristics and preferences, being a homeowner is associated with a reduction in the likelihood of being an entrepreneur; (ii) the negative link between homeownership and entrepreneurship is an increasing function of mortgage debt; and (iii) the negative relation is more pronounced for would-be entrepreneurs in risky sectors.

\footnotetext{
${ }^{28}$ In a similar vein, Disney and Gathergood (2009) replicate Hurst and Lusardi (2004) results using BHPS data and Taylor (1999) finds that housing equity does not affect the duration of self-employed ventures.
} 
In our empirical analysis we exploit the longitudinal dimension of the British Household Panel Survey to test for these predictions while controlling for individual tine-fixed unobservables and time-varying observables. Our findings confirm all three model predictions. This suggests that the negative link between homeownership and entrepreneurship is driven by the fact that the housing consumption of homeowners is less flexible than that of renters and that greater mortgage payment commitments amplify risk aversion. This reduces the likelihood that an individual will take up a risky entrepreneurial activity. We also empirically test an alternative mechanism based on credit constraints, whereby leveraged homebuyers are prevented from taking on additional credit to start a business. However, we find no evidence in support of this mechanism.

Our empirical analysis yields a number of other important insights. First, our evidence captures a negative link between homeownership and genuine entrepreneurship rather than self-employment out of necessity. Second, the negative link between entrepreneurship is strongest on impact - both in terms of statistical and economic significance - and then slowly fades away but always remains negative. Moreover there is a negative link prior to impact due to an anticipation effect. Third, our results are not driven by geographical mobility upon becoming homeowners.

Our findings have important policy implications. Virtually all developed countries - including the United States and the United Kingdom - have set in place policies that favor homeownership, mostly by making it easier to finance home purchases with a loan. These policies include mortgage interest rate deductibility, non-taxation of owner-occupation related capital gains and imputed rents, the creation of secondary mortgage markets and housing-finance giants (such as Fannie Mae and Freddie Mac) with implicit or explicit government backing or direct government guarantees of mortgages for first-time buyers. The recent financial crisis - the Great Recession - and recent research (Glaeser and Shapiro, 2003; Frame and White, 2005; Hilber and Turner, 2013) point out that these policies are associated with huge costs, are by and large ineffective and can have perverse effects by lowering homeownership attainment of low and moderate income households in locations where positive externalities of homeownership may be concentrated. Our findings suggest that, in addition to this, mortgage debt financed homeownership may significantly depress entrepreneurial activities, at least in the short- and medium-term, putting an additional question mark behind costly policies that aim to promote homeownership.

\section{References}

Acs, Zoltan, D. A. P. B. and Carlsson, B. (2004). The missing link: The knowledge filter and entrepreneurship in endogenous growth. CEPR Discussion Paper N, . 4783.

Adelino, M., Schoar, A., and Severino, F. (2013). House prices, collateral and self-employment. (18868).

Alba-Ramirez, A. (1994). Self-employment in the midst of unemployment: The case of Spain and the United States. Applied Economics, 26:189-204.

Battu, Harminder, A. M. and Phimister, E. (2008). Housing tenure, job mobility and unemployment in the UK. Economic Journal, 118:311-328.

BIS (Department for Business, Innovation and Skills) (2010). Evaluation of community development finance institutions. Technical report. London.

Black, J., de Meza, D., and Jefreys, D. (1996). House prices, the supply of collateral and the enterprise economy. Economic Journal, 106:60-75. 
Blanchflower, D. and Oswald, A. (1992). Entrepreneurship, happiness and supernormal returns: Evidence from britain and the us. NBER Working Papers 4228, National Bureau of Economic Research, Inc.

Blanchflower, D. and Oswald, A. (1998). What makes an entrepreneur? Journal of Labor Economics, $16(1): 26-60$.

Blanchflower, D. and Shadforth, C. (2007). Entrepreneurship in the UK. Foundations and Trends in Entrepreneurship, 3:1-108.

Brueckner, J. K. (1997). Consumption and investment motives and the portfolio choices of homeowners. Journal of Real Estate Finance and Economics, 15:159-180.

Chetty, R. and Szeidl, A. (2007). Consumption commitments and risk preferences. The Quarterly Journal of Economics, 122(2):831-877.

Chetty, R. and Szeidl, A. (2010). The effect of housing on portfolio choice. NBER Working Paper N, . 15998.

Cocco, J. (2005). Portfolio choice in the presence of housing. Review of Financial Studies, 18:535-567.

Davidoff, T. (2006). Labor income, housing prices, and homeownership. Journal of Urban Economics, $59: 209-235$.

Davis, M. A. and Ortalo-Magné, F. (2011). Household expenditures, wages, rents. Review of Economic Dynamics, 14(2):248-261.

De Meza, D. and Webb, D. (1999). Wealth, enterprise and credit policy. Economic Journal, 109:153-163.

Dehring, C. A., Depken II, C. A., and Ward, M. R. (2008). A direct test of the homevoter hypothesis. Journal of Urban Economics, 64(1):155-170.

Dietz, R. D. and Haurin, D. R. (2003). The social and private micro-level consequences of homeownership. Journal of Urban Economics, 54:401-450.

DiPasquale, D. and Glaeser, E. (1999). Incentives and social capital: are homeowners better citizens? Journal of Urban Economics, 45:354-384.

Disney, R. and Gathergood, J. (2009). Housing wealth, liquidity constraints and self-employment. Labour Economics, 16:79-88.

Engelhardt, G. (1996). Consumption, down payments, and liquidity constraints. Journal of Money, Credit and Banking, 28(2):255-71.

Evans, D. and Jovanovic, B. (1989). An estimated model of entrepreneurial choice under liquidity constraints. Journal of Political Economy, 87:808-827.

Evans, D. S. and Leighton, L. S. (1989). Some empirical aspects of entrepreneurship. American Economic Review, 79(3):519-35.

Faggio, G. and Silva, O. (2011). Does self-employment measure entrepreneurship? Evidence from Great Britain. mimeo, LSE.

Faig, M. and Shum, P. (2002). Portfolio choice in the presence of personal illiquid projects. Journal of Finance, 57(1):303-328. 
Fairlie, R. W. (2010). The great recession and entrepreneurship. mimeo, University of California Santa Cruz.

Fairlie, R. W. and Krashinsky, H. A. (2011). Liquidity constraints, household wealth, and entrepreneurship revisited. mimeo, University of California Santa Cruz.

Ferreira, F., Gyourko, J., and Tracy, J. (2010). Housing busts and household mobility. Journal of Urban Economics, $68,: 34-45$.

Fischel, W. A. (2001). Homevoters, municipal corporate governance, and the benefit view of the property tax. National Tax Journal, 54:157-173.

Flavin, M. and Nakagawa, S. (2008). A model of housing in the presence of adjustment costs: A structural interpretation of habit persistence. American Economic Review, 98(1):474-95.

Flavin, M. and Yamashita, T. (2002). Owner-occupied housing and the composition of the household portfolio. The American Economic Review, 92(1):345-362.

Frame, W. S. and White, L. (2005). Fussing and fuming over Fannie and Freddie: How much smoke, how much fire? Journal of Economic Perspectives, 19:159-184.

Glaeser, E. (2009). Entrepreneurship and the city. in Entrepreneurship and Openness: Theory and Evidence, D. Audretsch, R. Litan and R. Strom eds. (Northampton: Edward Elgar Publishing, ).

Glaeser, E. and Kerr, W. (2010). Local industrial conditions and entrepreneurship: How much of the spatial distribution can we explain? Journal of Economics and Management Strategy, 18 ,623-663.

Glaeser, E. L. and Shapiro, J. M. (2003). The benefits of the home mortgage interest deduction. In Tax Policy and the Economy, Volume 17, NBER Chapters, pages 37-82. National Bureau of Economic Research, Inc.

Hamilton, B. H. (2000). Does entrepreneurship pay? an empirical analysis of the returns to selfemployment. Journal of Political Economy, 108(3):604-631.

Harding, J. and Rosenthal, S. (2013). Homeowner-entrepreneurs, housing capital gains and selfemployment. Mimeo - Syracuse University.

Haurin, D. R. and Gill, H. L. (2002). The impact of transaction costs and the expected length of stay on homeownership. Journal of Urban Economics, 51:563-584.

Heaton, J. and Lucas, D. (2000). Portfolio choice and asset prices: The importance of entrepreneurial risk. Journal of Finance, 55(3):1163-1198.

Henderson, J. V. and Ioannides, Y. (1983). A model of housing tenure choice. American Economic Review, 73:98-113.

Hilber, C. (2005). Neighborhood externality risk and the homeownership status of properties. Journal of Urban Economics, 57:213-241.

Hilber, C. (2007). The determinants of homeownership across europe: Panel data evidence. mimeo LSE.

Hilber, C. (2010). New housing supply and the dilution of social capital. Journal of Urban Economics, $67: 419-437$. 
Hilber, C. and Mayer, C. (2009). Why do households without children support local public schools? Linking house price capitalization to school spending. Journal of Urban Economics, 65:74-90.

Hilber, C. and Turner, T. (2013). The mortgage interest deduction and its impact on homeownership decisions. Review of Economics and Statistics, forthcoming.

Hilber, C. and Vermeulen, W. (2012). The long-term impact of supply constraints on house prices in england. SERC Discussion paper, 119.

Hoff, K. and Sen, A. (2005). Homeownership, community interaction, and segregation. American Economic Review, 95,:1167-1189.

Holtz-Eakin, Donald, D. J. and Rosen, H. (1994). Sticking it out: Entrepreneurial survival and liquidity constraints. Journal of Political Economy, 102:53-75.

HUD (Department for Housing and Urban Development) (1995). The national homeownership strategy: Partners in the American dream. Technical report. Washington, DC.

Hurst, E. and Lusardi, A. (2004). Liquidity constraints, household wealth, and entrepreneurship. Journal of Political Economy, 112:319-347.

Hurst, E. and Pugsley, B. W. (2011). What do small businesses do? Brookings Papers on Economic Activity, 43(2 (Fall)):73-142.

Linneman, P. and Wachter, S. (1989). The impacts of borrowing constraints on homeownership. Journal of the American Real Estate and Urban Economics Association, 17:389-402.

Lucas, Jr, R. E. (1978). On the size distribution of business firms. The Bell Journal of Economics, pages 508-523.

Lustig, H. N. and Nieuwerburgh, S. G. V. (2005). Housing collateral, consumption insurance, and risk premia: An empirical perspective. Journal of Finance, 60(3):1167-1219.

Maré, D. (2006). Constructing consistent work-life histories: A guide for users of the british household panel survey.

Martinez-Granado, M. (2002). Self-employment and labour market transitions: A multiple state model. CEPR Discussion Paper 3661.

Michelacci, C. (2003). Low returns to r\&d due to the lack of entrepreneurial skills. Economic Journal, $113,207225$.

Michelacci, C. and Silva, O. (2007). Why so many local entrepreneurs? Review of Economics and Statistics, 89:615-633.

Muelbauer, J. (2002). Mortgage credit conditions in the UK. Economic Outlook, 25:10-17.

Munch, J. R., Rosholm, M., and Svarer, M. (2006). Are homeowners really more unemployed? Economic Journal, 116(514):991-1013.

Oswald, A. (1996). A conjecture on the explanation for high unemployment in the industrialised nations: Part 1. Warwick Economic Research Papers.

Oswald, A. (1998). The missing piece of the puzzle. CEPR Workshop on Unemployment Dynamics. 
Oswald, A. (1999). The housing market and Europe's unemployment: A non-technical paper. mimeo, University of Warwick.

Paull, G. (2002). Biases in reporting of labour market dynamics. IFS Working Paper.

Piazzesi, M., Schneider, M., and Tuzel, S. (2007). Housing, consumption and asset pricing. Journal of Financial Economics, 83(3):531-569.

Schumpeter, J. (1921). The Theory of Economic Development. Harvard University Press, Cambridge.

Shore, S. H. and Sinai, T. (2010). Commitment, risk, and consumption: Do birds of a feather have bigger nests? The Review of Economics and Statistics, 92(2):408-424.

Taylor, M. (1999). Survival of the fittest? an analysis of self-employment duration in Britain. Economic Journal, 119 , C140-C155.

Taylor, M. (2001). Self-employment and windfall gains in Britain: Evidence from panel data. Economica, $68: 539-565$.

Upward, R. (1999). Constructing data on unemployment spells from the PSID and the BHPS. Centre for Research on Globalisation and Labour Markets, School of Economic Studies, Nottingham.

USA Today (2011). Strategies: Homeownership is a small business issue, article by R. Abrams, appeared on line on $17 / 02$.

van Ham, M., Williamson, L., Feijten, P., and Boyle, P. (2010). Right to buy, time to move? investigating the effect of the right to buy on moving behaviour in the UK. IZA Discussion Paper, 5115.

Wang, S.-Y. (2012). Credit constraints, job mobility and entrepreneurship: Evidence from a property reform in china. Review of Economics and Statistics, forthcoming. 


\section{Appendices}

\section{A Analytical appendix: Proofs and extensions}

\section{A.1 Lemma 1}

An agent decides to be an entrepreneur if the expected utility of entrepreneurship is greater than the expected utility of dependent employment, i.e. if $\mathbb{E} V\left(Y_{e}\right)>\mathbb{E} V\left(Y_{w}\right)$. Using the mean-variance approximation of equation (1), and considering that $V^{\prime}(Y)$ drops out from this expression since $\mathbb{E}(\bar{Y}-Y)=0$, this translates to:

$$
\alpha_{i}+V(\bar{Y})+\frac{\sigma_{e}^{2}}{2} V^{\prime \prime}(\bar{Y})>V(\bar{Y})+\frac{\sigma_{w}^{2}}{2} V^{\prime \prime}(\bar{Y}),
$$

which leads to Lemma 1.

\section{A.2 Lemma 2}

The envelope theorem states that $V^{\prime}(\bar{Y})=U_{C}$ at the optimum. Using this equation and applying the chain rule, the second derivative of $V(\bar{Y})$ can be expressed as:

$$
V^{\prime \prime}(\bar{Y})=\frac{\mathrm{d} U_{C}}{\mathrm{~d} Y}=\frac{\partial U_{C}}{\partial C} \frac{\mathrm{d} C}{\mathrm{~d} Y}+\frac{\partial U_{C}}{\partial H} \frac{\mathrm{d} H}{\mathrm{~d} Y}=U_{C C} \frac{\mathrm{d} C}{\mathrm{~d} Y}+U_{C H} \frac{\mathrm{d} H}{\mathrm{~d} Y}
$$

When an agent owns a housing unit and cannot adjust housing consumption, then $\frac{\mathrm{d} C}{\mathrm{~d} Y}=1$ and $\frac{\mathrm{d} H}{\mathrm{~d} Y}=0$. The second derivative of the indirect utility function is just the second derivative of the utility function with respect to consumption, $U_{C C}$.

Using again the chain rule and dropping the subscript $i$ for simplicity, we can compute how $V_{O}^{\prime \prime}$ changes with $m$ :

$$
\frac{\mathrm{d} V_{O}^{\prime \prime}(\bar{Y})}{\mathrm{d} m}=\frac{\partial V_{O}^{\prime \prime}(\bar{Y})}{\partial C} \frac{\mathrm{d} C}{\mathrm{~d} m}=\underbrace{U_{C C C}}_{>0} \underbrace{\frac{\mathrm{d} C}{\mathrm{~d} m}}_{<0},
$$

where the first term is positive because of the prudence assumption and the second term is negative because an increase in housing costs reduces consumption.

\section{A.3 Proposition 1}

To begin with, let us define:

$$
\begin{aligned}
& U_{C C}^{O}(\bar{Y})=U_{C C}(\underset{+}{\bar{Y}}, \underset{-}{m}), \\
& U_{C C}^{R}(\bar{Y})=U_{C C}\left({ }_{+}^{\bar{Y}}, \underset{-}{r}\right),
\end{aligned}
$$

where the signs under the variables denote the direction of the derivative of $U_{C C}$ with respect to that variable.

Dropping again the subscript $i$ for simplicity, note that when $r=m$, the second derivative of the utility function with respect to consumption is identical irrespective of whether the individual owns or rents the property, i.e. $U_{C C}^{O}(\bar{Y})=U_{C C}^{R}(\bar{Y})=U_{C C}(\bar{Y}, r)$.

Next, consider that the sign of the fixed-effects coefficient depends on the sign of $V_{O}^{\prime \prime}(\bar{Y})-V_{R}^{\prime \prime}(\bar{Y})$, because these two terms determine the threshold for the entrepreneurial occupation choice of owners and 
renters, respectively. According to equation (4) and for $r=m$, we have that:

$$
V_{O}^{\prime \prime}(\bar{Y})-V_{R}^{\prime \prime}(\bar{Y})=U_{C C}(\bar{Y}, r)\left(1-\frac{\mathrm{d} C}{\mathrm{~d} Y}\right)-U_{C H}^{R}(\bar{Y}) \frac{\mathrm{d} H}{\mathrm{~d} Y},
$$

which is negative because $U_{C C}(\bar{Y}, r)$ is negative and $U_{C H} \geq 0$.

For $m<r$, the sign of the fixed-effects coefficient will be determined by the sign of:

$$
U_{C C}(\bar{Y}, r-\epsilon)-U_{C C}(\bar{Y}, r)\left(\frac{\mathrm{d} C}{\mathrm{~d} Y}\right)-U_{C H}^{R}(\bar{Y}) \frac{\mathrm{d} H}{\mathrm{~d} Y},
$$

where $\epsilon=r-m$. By continuity of $U_{C C}$, considering the fact that $\frac{\mathrm{d} U_{C C}}{\mathrm{~d} m}<0$, and given that $U_{C C}(\bar{Y}, r)-$ $U_{C C}(\bar{Y}, r)\left(\frac{\mathrm{d} C}{\mathrm{~d} Y}\right)<0$ when $m=r$, there exist an $\epsilon$ such that $U_{C C}(\bar{Y}, r-\epsilon)-U_{C C}(\bar{Y}, r)\left(\frac{\mathrm{d} C}{\mathrm{~d} Y}\right)<0$. Since $\left(-U_{C H}^{R}\right)$ is always negative, Proposition 1 is proven.

Notice that, in reality, $\frac{\mathrm{d} C}{\mathrm{~d} Y}$ is likely to be around $75 \%$ (Davis and Ortalo-Magné, 2011). Therefore, the sign of the fixed-effects coefficient is negative as long as:

$$
U_{C C}(\bar{Y}, r-\epsilon)<0.75 U_{C C}(\bar{Y}, r) .
$$

This expression clarifies what " $m$ close to $r$ " means in Proposition 1.

As a matter of fact, in our empirical investigation we find that the link between homeownership and entrepreneurship stays negative (although not significantly different from zero) for individuals who have repaid their mortgage, i.e. when $m \rightarrow 0$. This implies:

$$
\lim _{m \rightarrow 0} U_{C C}(\bar{Y}, m)=U_{C C}(\bar{Y}, r)\left(\frac{\mathrm{d} C}{\mathrm{~d} Y}\right)-U_{C H}^{R}(\bar{Y}) \frac{\mathrm{d} H}{\mathrm{~d} Y},
$$

suggesting that for all values of $m<r$ the fixed-effects coefficient will be non-positive.

\section{A.4 The tenure decision}

A dependent worker decides to own a house if the expected utility of doing so exceeds the expected utility of renting, i.e. $\mathbb{E} V_{O}\left(Y_{w}\right)>\mathbb{E} V_{R}\left(Y_{w}\right)$. Using the mean-variance approximation of equation (1) in Section 3 , this means that a dependent worker chooses to own when the benefits of homeownership exceed its costs:

$$
\underbrace{V_{O}(\bar{Y})-V_{R}(\bar{Y})}_{\text {ownership benefits }}>\underbrace{\frac{\sigma_{w}^{2}}{2}\left[-V_{O}^{\prime \prime}(\bar{Y})+V_{R}^{\prime \prime}(\bar{Y})\right]}_{\text {ownership costs }} .
$$

To compute the costs involved in the commitment to own a house relative to renting, we exploit Lemma 2 and note that, in the case of homeownership $V_{O}^{\prime \prime}(\bar{Y})=U_{C C}^{O}$. The cost of homeownership is therefore:

$$
\frac{\sigma_{w}^{2}}{2}\left[-U_{C C}^{O}\left(m_{i}\right)+U_{C C}^{R} \frac{\mathrm{d} C}{\mathrm{~d} Y}+U_{C H}^{R} \frac{\mathrm{d} H}{\mathrm{~d} Y}\right] .
$$

This expression highlights that the cost of homeownership positively depends on $m_{i}$. As discussed above in A.3, we assume that the term in the square bracket stays positive as $m_{i} \rightarrow 0$, i.e. the cost due to commitment is substantial; as noted, this assumption is supported by our data. A positive term is however not required for our model to generate Proposition 2 and 3.

Conversely, the benefits of home-ownership depend negatively on $m_{i}$. To see this, recall that for an 
owner-occupier $Y=C+m_{i} \bar{H}$ and that only an amount of housing fixed at level $\bar{H}$ can be consumed. A higher $m_{i}$ reduces consumption of goods other than housing, thus reducing utility.

Taking rents $r$ as fixed, this implies that the comparison between the costs and benefits of homeownership depends on the costs of owner-occupied housing $m_{i}$ in the following way:

- If $m_{i}=r$ there are no benefits to homeownership, but there is a positive cost in terms of commitment. This implies individuals will rent.

- if $m_{i}=0$ - i.e. owning is costless in the sense that the mortgage has been fully repaid - we assume that the benefits of owning exceed the costs. This assumption is not untenable, as it merely states that the benefits of consuming the same housing without paying anything relative to paying $r$ more than compensate for the commitment cost. This assumption also guarantees that homeownership is a feasible equilibrium outcome in our model - i.e. it allows the model to replicate a matter of reality.

- If $m_{i}<r$, by continuity there must be a value of $m_{i}=m_{w}^{*}$, such that a dependent worker is indifferent between owning and renting.

Note that for values $m_{i}>r$ homeownership is more expensive than renting and there is a positive cost in terms of commitment. As a result no individual will ever choose to own. Given that this configuration of the model parameters does not appear to be particularly relevant, in our theoretical framework we only consider the more likely cases where $m_{i} \leq r$.

For entrepreneurs the choice is similar. The benefits of owning are identical to those discussed above. To compute the costs, one just needs to substitute $\sigma_{w}^{2}$ with $\sigma_{e}^{2}$ in equation (5). This shows that the cost of homeownership is higher for entrepreneurs because the term in parenthesis in (5) is multiplied by a higher variance. ${ }^{29}$ This implies that entrepreneurs will only be homeowners if $m_{i}$ is below a threshold $m_{e}^{*}$, with $m_{e}^{*}<m_{w}^{*}$.

We sketch these relations in Figure 1, where we present a linear approximation of the benefits and costs of homeownership for dependent workers and entrepreneurs. The exact values of $m_{e}^{*}$ and $m_{w}^{*}$ depend in an implicit way on the exact shape of the utility function and on values of $\sigma_{e}^{2}$ and $\sigma_{w}^{2}$.

Finally, note that, in our one-period framework, individuals simultaneously choose their tenure status and their occupation. The latter decision depends on the relative riskiness of the two occupations, the shape of the utility function and individuals' preference for entrepreneurship, i.e. $\alpha_{i}$. A closed form characterization of the model cannot be provided. However, its main predictions are that individuals with high $\alpha_{i}$ and low $m_{i}$ will be owner-entrepreneurs, whereas individuals with low $\alpha_{i}$ and high $m_{i}$ will be renter-dependent workers. There will also be parameter configurations giving rise to renterentrepreneurs and owner-dependent workers. Lastly, there will be regions where individuals with the same $\alpha_{i}$ can choose any of the four possible combinations of occupational and tenure choice depending on the exact parametrization of the utility function, their idiosyncratic cost of homeownership $m_{i}$, and the relative position of $\sigma_{e}^{2}$ and $\sigma_{w}^{2}$. This implies that in an OLS regression with entrepreneurship as dependent variable, the sign of the coefficient of the homeownership variable is ambiguous and depends on all the unobservable model parameters.

\footnotetext{
${ }^{29}$ Note also that the cost of homeownership for entrepreneurs is higher than the same cost for dependent workers even if $m=0$. This is because ownership costs are multiplied by $\sigma_{e}^{2}>\sigma_{w}^{2}$.
} 


\section{Figure A.1: Housing tenure Choice}

Notes: The figure depicts the costs and benefits of homeownership. For entrepreneurs the slope of the cost line is steeper and its intercept is higher, which leads to a lower $m^{*}$ (the ownership cost which makes an agent indifferent between owning or renting).

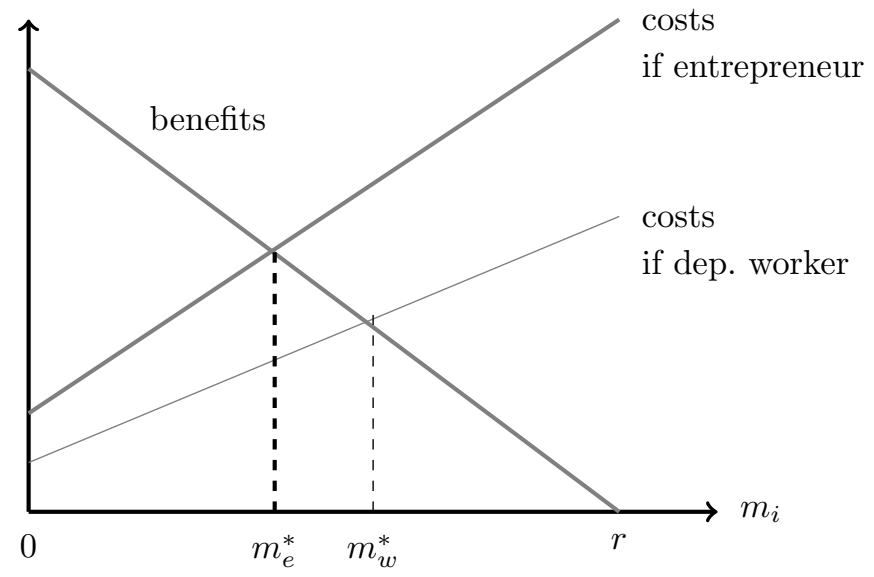

\section{B Construction of monthly job histories from the British House- hold Panel Survey}

In this section, we provide a description of the way we construct monthly job spells and solve inconsistencies in the BHPS. We follow the principle that information recorded closest to the date of the beginning of the spell is the most accurate. A similar approach is used in Upward (1999) and Battu and Phimister (2008).

To begin with, consider that the BHPS contains a longitudinal file identifying every person that ever appeared in the survey, indicating in which waves he or she was interviewed. From this file we construct the list of individuals that belong to the initial sample, i.e. those with a full interview in Wave 1, as well as those who fill in a full interview for the first time in one of the subsequent waves.

Next, in every wave of the BHPS, interviewed individuals appear in a 'respondent file', which contains information on the current labor force and occupational status - and if they have changed their labor market status between two waves - in a 'job history file' that collects detailed information for every occupational spell, such as job characteristics, starting date, ending date and sector of occupation. In order to construct labor market spells, we use the following iterative strategy for every wave, starting from Wave 1 (1991) or the first wave in which an individual first appears, and working towards to the most recent wave (Wave 18 in 2008):

1. We carry out consistency checks in the 'job history file' and, separately, in the 'respondent file' (more details on this below);

2. We append the 'respondent file' on top of the 'job history file' in order to check the consistency between the two - in particular regarding the starting date of the current job and the history of jobs reported in the history file. We name the resulting file 'wave w' file, where w indicates the wave under consideration;

3. We append the file 'wave w' on top of the combined file from the previous wave, that is, 'wave w-1', and check the consistency of the information provided in the two files. 
4. Once we have appended all waves, we compute the duration in months of every spell and we expand the dataset so that every observation corresponds now to one specific month. We call the resulting file the 'labor spell file'.

In the original data, every labor market spell comes with a starting/ending date, and inconsistencies arise because of overlaps between these dates. In order to address inconsistencies, we look for problematic cases both: (a) in the within-file, i.e. within the 'job history file' and separately within the 'respondent file'; and (b) within-wave, i.e. within the combined file obtained by appending the 'respondent' and the 'job history' files. The general idea is to resolve overlaps by preferring answers recorded closest to the date of the beginning of the spell. Note that our 'within-file' and 'within-wave' approach also solves situations that could arise because of between-wave overlaps. In detail, we proceed as follows:

- Within-file checks: (a) Spells that display a starting date earlier than the interview of the previous year are recoded as starting on the day of the interview of the previous year. This is because, up to the date of the previous interview, we trust information from the previous wave more than retrospective information; (b) Spells starting after the current date of interview are considered as starting on the date of interview. Discrepancies of this type probably emerge as a coding error in the original data; (c) For the 'job history file' only, we check that the sequence of spell starting dates is increasing. If this is not the case, we drop the spell(s) that cause the inconsistency.

- Within-wave checks: (a) If a spell from the 'job history file' has a missing starting date, the starting date is imputed as the mean of the starting dates of the two adjacent job history spells. Stated differently, we center this job spell in the middle of the two adjacent ones; (b) If a spell from the 'respondent file' has a missing starting date, two possibilities arise. If there is no 'job history file' spell for the same individual, the starting date of this spell is imputed as the date of the previous interview. If instead there is a pre-dating spell in the 'job history file', the starting date of the current job is imputed as the date of the current interview; (c) We check that the sequence of starting dates in the combined 'respondent'/'job history' file - i.e. the 'wave' file —is increasing. If not, we drop the spell that causes the inconsistency; (d) We check that point (c) holds true when we iteratively append 'wave files' from subsequent waves of the BHPS. 


\section{Tables and figures}

TABLE 1: SUMMARY STATISTICS - BHPS INDIVIDUAL LEVEL MONTHLY DATASET

\begin{tabular}{lrr}
\hline \hline Variable & Mean & Std. Dev. \\
\hline Panel A: Entrepreneurs + homeowners & & \\
Entrepreneurs & 0.047 & 0.212 \\
Homeowner & 0.811 & 0.391 \\
Homeowner, with mortgage & 0.714 & 0.451 \\
Homeowners, outright (no mortgage) & 0.096 & 0.295 \\
Loan-to-value ratio on outstanding mortgage (owners with mortgage) & 0.485 & 0.259 \\
House value (all owners) & $119,887.6$ & $109,051.6$ \\
Monthly mortgage payment (owners with mortgage) & 379.1 & 281.6 \\
\hline Panel B: Controls & & \\
Age & 39.38 & 0.95 \\
Male & 0.788 & 0.409 \\
Household total income (previous year) & $31,728.0$ & $22,046.3$ \\
Individual total income (previous year) & $20,990.0$ & $16,144.4$ \\
Children under 16 (yes=1, no=0) & 0.457 & 0.498 \\
Coupled (yes=1, no=0) & 0.745 & 0.436 \\
Education: Higher Degree & 0.039 & 0.193 \\
Education: First Degree & 0.151 & 0.358 \\
Education: Higher Non Degree/Teaching Qual. & 0.080 & 0.272 \\
Education: A Level (or equiv.) & 0.228 & 0.419 \\
Education: O Level (or equiv.) & 0.265 & 0.441 \\
Education: CSE (or equiv.) & 0.071 \\
Education: None of these & 0.166 \\
\hline
\end{tabular}

Note: The sample only includes heads of household aged between 20 and 55 living in England (excludes Scotland and Wales). Summary statistics of control variables refer to the sample where all controls are non-missing. Number of observations: 366168. Number of individuals: 5193. Panel is unbalanced. 'Entrepreneur' includes self-employed with dependent employees; 'Entrepreneur: manager' includes entrepreneur in managerial and professional jobs. Loan-to-value ratio of outstanding mortgage is time-varying and calculated as value of outstanding mortgage liabilities divided individual self-reported assessment of property value (measured in GB pounds). LTV capped at 1.25; values above 1.25 recoded as missing. House value is time-varying, self-reported and measured in GB pounds. Monthly mortgage payment refers to the month prior to the interview (time varying, self-reported and measures in GB pounds). In the regression analysis age is controlled semi-parametrically by including the following dummies: age between 20 and 24; age between 25 and 29; age between 30 and 34; age between 35 and 39; age between 40 and 44; age between 45 and 49; age between 50 and 54 ; age 50 or above. 
TABLE 2: SUMMARY STATISTICS - INCOME VARIATION FOR WORKERS AND ENTREPRENEURS

\begin{tabular}{lcccc}
\hline \hline Individual total income (previous year): & Mean & Median & $\begin{array}{c}\text { Standard } \\
\text { Deviation }\end{array}$ & $\begin{array}{c}\text { Within-individual } \\
\text { Standard Deviation }\end{array}$ \\
\hline Dependent workers (employees) & $21,194.6$ & $18,332.0$ & $14,528.1$ & 7049.7 \\
Entrepreneurs: dependent & $27,407.1$ & $18,500.0$ & $33,608.4$ & $14,354.5$ \\
\hline \hline
\end{tabular}

Note: Within-individual standard deviation shows average within-individual over-time standard deviation of individual income for different employment categories. See Table 1a for further information on sample construction and variable definitions.

TABLE 3: TRANSITIONS INTO AND OUT OF HOMEOWNERSHIP AND ENTREPRENEURSHIP

\begin{tabular}{|c|c|c|}
\hline & \multicolumn{2}{|c|}{$\%$ (numbers) of individuals making at least... } \\
\hline & One transition & Two transitions \\
\hline \multicolumn{3}{|c|}{ Panel A: Homeownership } \\
\hline Overall & $18.3(950)$ & $5.8(301)$ \\
\hline Transition in & $13.3(691)$ & $0.9(47)$ \\
\hline Transition out & $10.8(561)$ & $1.0(52)$ \\
\hline \multicolumn{3}{|c|}{ Panel B: Homeownership with mortgage } \\
\hline Overall & $25.5(1324)$ & $7.7(400)$ \\
\hline Transition in & $16.2(841)$ & $1.4(73)$ \\
\hline Transition out & $17.1(888)$ & $1.7(88)$ \\
\hline \multicolumn{3}{|c|}{ Panel C: Homeownership without mortgage } \\
\hline Overall & $12.6(654)$ & $3.6(187)$ \\
\hline Transition in & $9.7(504)$ & $1.0(52)$ \\
\hline Transition out & $6.5(338)$ & $0.6(31)$ \\
\hline \multicolumn{3}{|c|}{ Panel D: Entrepreneur, dependent } \\
\hline Overall & $5.9(306)$ & $3.3(171)$ \\
\hline Transition in & $4.8(249)$ & $1.1(57)$ \\
\hline Transition out & $4.4(228)$ & $1.0(52)$ \\
\hline
\end{tabular}

Note: The sample only includes heads of household aged between 20 and 55 living in England (excludes Scotland and Wales). Total number of individuals: 5193. Panel is unbalanced. 
TABLE 4: SUMMARY STATISTICS OF INDIVIDUAL CHARACTERISTICS TIME OF TRANSITIONS INTO AND OUT OF HOMEOWNERSHIP AND ENTREPRENEURSHIP

Time of transition into...

Time of transition out of...

Panel A: Homeownership with mortgage

Age $30.35(7.87)$ $33.88(9.22)$

Children

$0.325(0.469)$

$0.378(0.485)$

Coupled

$0.623(0.485)$

$0.626(0.484)$

Individual total income

$13646.9(9161.0)$

$14968.9(10417.9)$

Panel B: Homeownership without mortgage

Age $37.40(8.49)$ $32.31(8.82)$

Children $0.429(0.495)$ $0.302(0.460)$

Coupled

$0.677(0.468)$

$0.559(0.497)$

Individual total income $16105.4(11780.9)$ 14596.3 (10715.4)

Panel C: Entrepreneur

Age $35.42(8.42)$ $35.89(8.13)$

Children

$0.494(0.501)$

$0.498(0.501)$

Coupled

$0.803(0.398)$

$0.830(0.377)$

Individual total income

$17538.7(15245.7)$

$17224.6(14896.1)$

Note: Sample includes heads of household aged between 20 and 55 living in England (excludes Scotland and Wales). Number of individuals: 5193. Panel is unbalanced. Figures are means and standard deviations (in parenthesis) of listed characteristic. 
TABLE 5: HOMEOWNERSHIP AND ENTREPRENEURSHIP - OLS AND FIXED-EFFECT REGRESSIONS

\begin{tabular}{|c|c|c|c|c|c|c|c|}
\hline & (1) & (2) & (3) & (4) & (5) & (6) & (7) \\
\hline $\begin{array}{l}\text { Dependent } \\
\text { variable is: } \\
\text { Entrepreneur }\end{array}$ & OLS & OLS & $\begin{array}{c}\text { FE } \\
\text { All } \\
\text { Trans. }\end{array}$ & $\begin{array}{c}\text { FE } \\
\text { All } \\
\text { Trans. }\end{array}$ & $\begin{array}{c}\text { FE } \\
\text { All } \\
\text { Trans. }\end{array}$ & $\begin{array}{c}\text { FE } \\
\text { Trans. In }\end{array}$ & $\begin{array}{c}\text { FE } \\
\text { Tran. Out }\end{array}$ \\
\hline Homeowner & $\begin{array}{c}0.036 \\
(0.006)^{* * *}\end{array}$ & $\begin{array}{c}0.014 \\
(0.006)^{* *}\end{array}$ & $\begin{array}{c}-0.011 \\
(0.005)^{* *}\end{array}$ & $\begin{array}{c}-0.012 \\
(0.006)^{* *}\end{array}$ & $\begin{array}{c}-0.013 \\
(0.005)^{* *}\end{array}$ & $\begin{array}{c}-0.022 \\
(0.009)^{* *}\end{array}$ & $\begin{array}{l}-0.009 \\
(0.010)\end{array}$ \\
\hline $\begin{array}{l}\text { Year \& month } \\
\text { dummies }\end{array}$ & Yes & Yes & Yes & Yes & Yes & Yes & Yes \\
\hline Sector dummies & Yes & Yes & Yes & Yes & Yes & Yes & Yes \\
\hline LPA dummies & No & Yes & No & Yes & No & No & No \\
\hline Controls & No & Yes & No & Yes & Yes & Yes & Yes \\
\hline
\end{tabular}

Note: See Table 1 for further information on sample characteristics and variable definitions. Year dummies refer to the year when the BHPS interview was carried out. Month dummies refer to calendar months during which the employment spell took place. LA dummies refer to the Local Planning Authority of residence (343 LPAs matched to English-resident BHPS individuals). Household and individual income included in logs. Column (6) only includes people who are or become homeowners. Column (7) only includes people who are or become renters. **: $5 \%$ significant; ***: $1 \%$ significant. Controls as listed in Table 1.

TABLE 6: HOMEOWNERSHIP AND ENTREPRENEURSHIP - TIMING AND DYNAMICS

\begin{tabular}{|c|c|c|c|}
\hline & $\begin{array}{l}\text { (1) } \\
\text { FE } \\
\text { No Input } \\
\text { Trans. Date }\end{array}$ & $\begin{array}{l}\text { (2) } \\
\text { FE } \\
\text { Duration } \\
\text { Linear }\end{array}$ & $\begin{array}{l}\text { (3) } \\
\text { FE } \\
\text { Duration } \\
\text { Squared }\end{array}$ \\
\hline Homeowner & $\begin{array}{c}-0.017 \\
(0.006)^{* * *}\end{array}$ & $\begin{array}{c}-0.013 \\
(0.006)^{* *}\end{array}$ & $\begin{array}{c}-0.018 \\
(0.006)^{* * *}\end{array}$ \\
\hline HO Duration $(\times 100)$ & & $\begin{array}{c}0.003 \\
(0.005)\end{array}$ & $\begin{array}{c}0.016 \\
(0.008)^{* *}\end{array}$ \\
\hline HO Duration Squared $(\times 1000)$ & & & $\begin{array}{c}-0.0005 \\
(0.0003)^{*}\end{array}$ \\
\hline \multicolumn{4}{|c|}{$\begin{array}{l}\text { Note: Regressions run on the monthly dataset. All regressions include year dummies; monthly Dummies; SIC92 1-digit } \\
\text { sector dummies; and individual controls. See notes to Table } 1 \text { and } 2 \text { for more details. Standard errors clustered at the } \\
\text { LA level. *: } 10 \% \text { significant; **: } 5 \% \text { significant; ***: } 1 \% \text { significant. Column (1) excludes individuals with imputed } \\
\text { transition date into homeownership (approx. } 7.3 \%) \text {. Columns }(2) \text { and (3) controls for number of months since becoming } \\
\text { homeowner (linear and squared terms). Descriptive statistics for duration in months as follows: mean }=122.22 ; \text { std. } \\
\text { dev. = 83.12. }\end{array}$} \\
\hline
\end{tabular}




\begin{tabular}{|c|c|c|c|c|c|c|}
\hline & (1) & $(2)$ & $(3)$ & (4) & $(5)$ & $(6)$ \\
\hline & FE & FE & $\mathrm{FE}$ & $\mathrm{FE}+\mathrm{IV}$ & FE & FE \\
\hline & $\begin{array}{l}\text { All } \\
\text { obs. }\end{array}$ & $\begin{array}{l}\text { All } \\
\text { obs. }\end{array}$ & $\begin{array}{l}\text { All } \\
\text { obs. }\end{array}$ & $\begin{array}{l}\text { All } \\
\text { obs. }\end{array}$ & $\begin{array}{l}\text { High profit } \\
\text { variability }\end{array}$ & $\begin{array}{l}\text { Low profit } \\
\text { variability }\end{array}$ \\
\hline Homeowner & $\begin{array}{l}-0.002 \\
(0.009)\end{array}$ & $\begin{array}{l}-0.000 \\
(0.007)\end{array}$ & & & & \\
\hline Homeowner, mortgage & $\begin{array}{c}-0.012 \\
(0.007)^{*}\end{array}$ & & & & & \\
\hline $\begin{array}{l}\text { Loan-to-value (LTV) of } \\
\text { mortgage }\end{array}$ & & $\begin{array}{c}-0.015 \\
(0.008) * * *\end{array}$ & $\begin{array}{c}-0.013 \\
(0.006)^{* *}\end{array}$ & $\begin{array}{c}-0.022 \\
(0.012)^{*}\end{array}$ & $\begin{array}{c}-0.017 \\
(0.009)^{* *}\end{array}$ & $\begin{array}{l}-0.004 \\
(0.006)\end{array}$ \\
\hline Additional controls & -- & -- & $\begin{array}{l}\text { House } \\
\text { Value }\end{array}$ & $\begin{array}{l}\text { House } \\
\text { Value }\end{array}$ & $\begin{array}{l}\text { House } \\
\text { Value }\end{array}$ & $\begin{array}{l}\text { House } \\
\text { Value }\end{array}$ \\
\hline $\begin{array}{l}\text { First-stage: } \\
\text { Coeff. (s.e.) on } \\
\text { instrument }\end{array}$ & -- & -- & -- & $\begin{array}{c}0.826 \\
(0.022)\end{array}$ & -- & -- \\
\hline T-Stat on instrument & -- & -- & -- & 38.31 & -- & -- \\
\hline
\end{tabular}

Note: Regressions run on the monthly dataset. All regressions include year dummies; monthly dummies; SIC92 1-digit sector dummies; and individual controls. See notes to Table 2 for more details. Standard errors clustered at the LPA level. *: $10 \%$ significant; **: $5 \%$ significant; ***: $1 \%$ significant. Loan-to-value (LTV) of outstanding mortgage calculated using outstanding amount of mortgage and individual's assessment of property value. LTV capped at 1.25; values above 1.25 recoded as missing. Instrumental variable regressions instrument individual's LTV with local LTV. This measure is obtained using data from the Survey of Mortgage Lenders at the LPA level. The instruments are timevarying and set to zero for years in which individuals are renters. Descriptive statistics of local LTV as follows. Mean $=0.751$; std.dev. $=0.059$. Columns (5) and (6) split the dependent variable using the median of the coefficient of variation of profits in the sector of employment. Data obtained from Eurostat for the years 1997 to 2007. Median values of the coefficient of variation of profits: 0.1348 . 


\begin{tabular}{|c|c|c|c|c|c|c|}
\hline & (1) & $(2)$ & (3) & (4) & $(5)$ & (6) \\
\hline & $\begin{array}{c}\text { FE } \\
\text { House } \\
\text { Prices }\end{array}$ & $\begin{array}{c}\text { FE } \\
\text { House } \\
\text { Prices }\end{array}$ & $\begin{array}{c}\mathrm{FE}+\mathrm{IV} \\
\text { House } \\
\text { Prices }\end{array}$ & $\begin{array}{c}\mathrm{FE}+\mathrm{IV} \\
\text { House } \\
\text { Prices }\end{array}$ & $\begin{array}{c}\text { FE } \\
\text { Capital } \\
\text { Needs }\end{array}$ & $\begin{array}{c}\mathrm{FE}+\mathrm{IV} \\
\text { Capital } \\
\text { Needs }\end{array}$ \\
\hline Homeowner & $\begin{array}{c}-0.012 \\
(0.006)^{* *}\end{array}$ & $\begin{array}{c}-0.014 \\
(0.006)^{* *}\end{array}$ & $\begin{array}{c}-0.014 \\
(0.005)^{* *}\end{array}$ & $\begin{array}{c}-0.013 \\
(0.006)^{* *}\end{array}$ & $\begin{array}{c}-0.014 \\
(0.007)^{* *}\end{array}$ & $\begin{array}{c}-0.015 \\
(0.008)^{*}\end{array}$ \\
\hline Local HP (logs) & $\begin{array}{l}-0.002 \\
(0.012)\end{array}$ & & & & & \\
\hline Cumulative HP gains & & $\begin{array}{c}0.001 \\
(0.003)\end{array}$ & $\begin{array}{c}0.001 \\
(0.006)\end{array}$ & $\begin{array}{c}0.001 \\
(0.007)\end{array}$ & & $\begin{array}{c}0.007 \\
(0.008)\end{array}$ \\
\hline $\begin{array}{l}\text { Capital × } \\
\text { Homeowner }(x 100)\end{array}$ & & & & & $\begin{array}{c}0.004 \\
(0.006)\end{array}$ & $\begin{array}{c}0.005 \\
(0.007)\end{array}$ \\
\hline $\begin{array}{l}\text { Capital } \times \text { Cumulative } \\
\text { HP gains }(x 100)\end{array}$ & & & & & & $\begin{array}{l}-0.005 \\
(0.004)\end{array}$ \\
\hline $\begin{array}{l}\text { House Price } \\
\text { Measure }\end{array}$ & $\begin{array}{c}\text { Local } \\
(\mathrm{LA})\end{array}$ & $\begin{array}{c}\text { Self- } \\
\text { Reported }\end{array}$ & $\begin{array}{c}\text { Self- } \\
\text { Reported }\end{array}$ & $\begin{array}{l}\text { Local } \\
(\mathrm{LA})\end{array}$ & -- & $\begin{array}{c}\text { Self- } \\
\text { Reported }\end{array}$ \\
\hline $\begin{array}{l}\text { First-stage F-test: } \\
\text { Cumulative HP gains }\end{array}$ & -- & -- & 248.17 & 423.46 & -- & 79.41 \\
\hline Capital $\times$ cum. HP gains & -- & -- & -- & -- & -- & 26.06 \\
\hline
\end{tabular}

Note: Regressions run on the monthly dataset. All regressions include year dummies; monthly dummies; SIC92 1-digit sector dummies; and individual controls. See notes to Table 1 and 2 for more details. Standard errors clustered at the LA level. *: $10 \%$ significant; **: $5 \%$ significant; ***: $1 \%$ significant. Column (1) includes (log of) local house prices (HP) alongside LA dummies. Columns (2), (3), (4) and (6) include cumulative HP gain measured as the cumulative house price change experienced by homeowners from time of purchase up to the period under consideration. Individual selfreported housing values used in Columns (2), (3) and (6). Housing price series obtained from the Survey of Mortgage Landers and Land Registry data at the LA level used in Column (4). Descriptive statistics of cumulative gain for homeowners as follows. Self-reported: mean $=0.664$; s.d. $=1.172$. LA level: mean=0.479; s.d. $=0.783$. Columns (3), (4) and (6) instrument cumulative house price gains using national house price cumulative gains interacted with LA-level percentage of developed land and LA-level refusal rates. Column (5) and (6) interact homeownership and cumulative house prices with the capital spending per occupied worker in the sector of employment. Data obtained from Eurostat for the years 1997 to 2007 and averaged across available years. Data merged using NACE sector at the 2-digit level. Column (6) instruments the interaction of capital requirements with cumulative HP gains using the product of the sectoral capital requirements with the national house price cumulative gains interacted with LA-level percentage of developed land and LA-level refusal rates. 


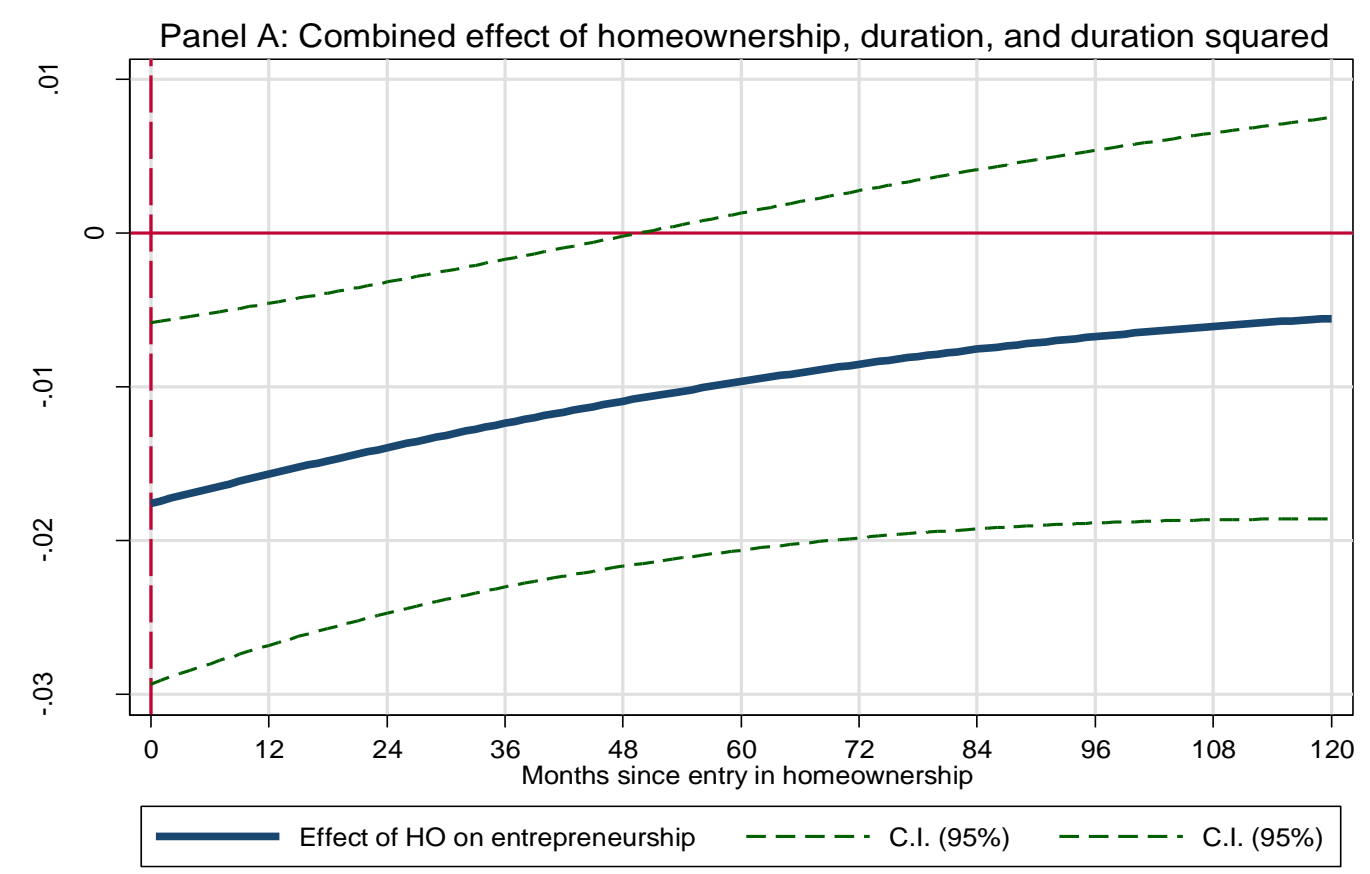

Panel B: Effect of homeownership on entrepreneurship, leads and lags

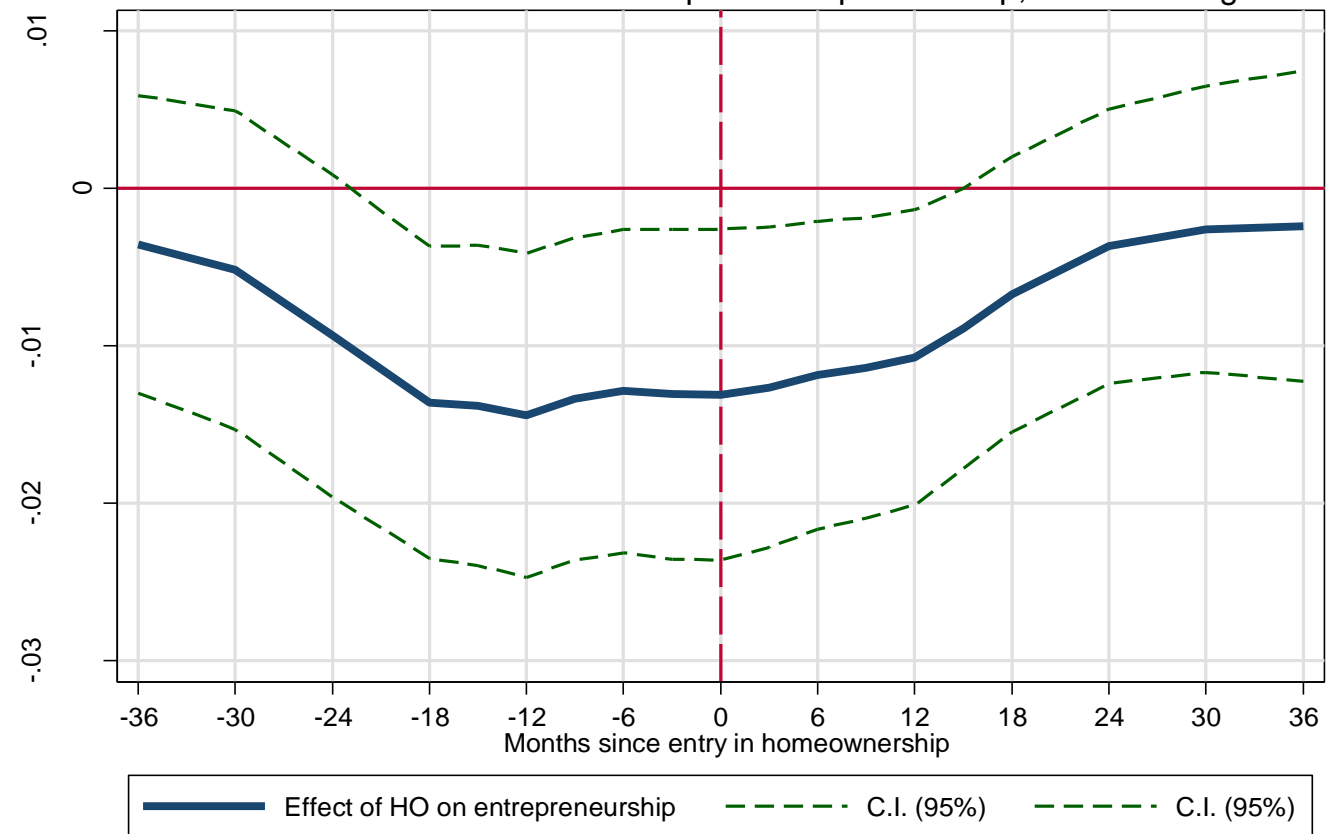

Note: Results used to obtain the graph in Panel A come from the specification presented in Table 3, Column (3). Results used to obtain the graph in Panel B come from 19 separate regressions of lag/lead of entrepreneurship on current homeownership status, conditional on the usual controls. See notes to Table 3 for more details. Dashed lines are confidence intervals at the $95 \%$ level obtained from standard errors clustered at the LA level. 


\section{Appendix C - Additional Tables}

APPENDIX TABLE 1: ENTREPRENEURS WITH DEPENDENT WORKERS - ROBUSTNESS AND HETEROGENEITY

\begin{tabular}{|c|c|c|c|c|c|c|c|c|}
\hline & (1) & $(2)$ & (3) & (4) & (5) & (6) & (7) & (8) \\
\hline & All Self-Emp. & $\begin{array}{c}\text { Entrep. } \\
\text { Managers }\end{array}$ & $\begin{array}{l}\text { Including } \\
\text { UN Spells }\end{array}$ & $\begin{array}{c}\text { Immobile } \\
\text { Workers }\end{array}$ & $\begin{array}{l}\text { Excluding } \\
\text { London }\end{array}$ & $\begin{array}{l}\text { Excl. Selected } \\
\text { Sectors }\end{array}$ & $\begin{array}{l}\text { Services } \\
\text { Only }\end{array}$ & $\begin{array}{c}\text { Manuf. } \\
\text { Only }\end{array}$ \\
\hline Homeowner & $\begin{array}{c}-0.015 \\
(0.008)^{*}\end{array}$ & $\begin{array}{c}-0.017 \\
(0.006)^{* * *}\end{array}$ & $\begin{array}{c}-0.013 \\
(0.005)^{* *}\end{array}$ & $\begin{array}{c}-0.010 \\
(0.006)^{*}\end{array}$ & $\begin{array}{c}-0.014 \\
(0.006)^{* *}\end{array}$ & $\begin{array}{c}-0.012 \\
(0.006)^{* *}\end{array}$ & $\begin{array}{c}-0.013 \\
(0.007)^{* *}\end{array}$ & $\begin{array}{l}-0.003 \\
(0.004)\end{array}$ \\
\hline
\end{tabular}

Note: All regressions include year dummies; monthly dummies; SIC92 1-digit sector dummies; and individual controls. See notes to Tables 1 and 2 for more details. Standard errors clustered at the LPA level. *: $10 \%$ significant; **: $5 \%$ significant; $* * *: 1 \%$ significant. Column (1) includes all self-employed; Column (2) includes self-employed in managerial and professional jobs. Column (3) includes unemployment spells. Column (4) only considers individuals always living either in urban areas or in rural areas (no urban-to-rural and rural-to-urban movers). Urban and rural areas determined on the basis of population density. See Faggio and Silva (2012) for more details. This sample includes approximately $87 \%$ of the observations. Column (5) excludes London; sample includes around 88\% of the observations. Regressions in Colum (6) exclude the following sectors: Agriculture; Fishing and Forestry; Mining. Electricity, Gas and Water; Public Administration; Household with Employees; and International Organizations. Sample includes approximately $88 \%$ of the observations. Samples including only workers in manufacturing and services include approximately $24 \%$ and $56 \%$ of the observations, 


\begin{tabular}{|c|c|c|c|c|c|}
\hline & (1) & (2) & (3) & (4) & (5) \\
\hline & $\begin{array}{c}\text { FE + IV } \\
\text { All } \\
\text { observations }\end{array}$ & $\begin{array}{c}\text { FE } \\
\text { All } \\
\text { observations }\end{array}$ & $\begin{array}{c}\mathrm{FE}+\mathrm{IV} \\
\text { All } \\
\text { observations }\end{array}$ & $\begin{array}{l}\text { FE } \\
\text { High price } \\
\text { variability }\end{array}$ & $\begin{array}{c}\text { FE } \\
\text { Low price } \\
\text { variability }\end{array}$ \\
\hline $\begin{array}{l}\text { Loan-to-value (LTV) of } \\
\text { outstanding mortgage }\end{array}$ & $\begin{array}{c}-0.022 \\
(0.012)^{*}\end{array}$ & & & $\begin{array}{l}-0.013 \\
(0.012)\end{array}$ & $\begin{array}{l}-0.012 \\
(0.010)\end{array}$ \\
\hline $\begin{array}{l}\text { Log monthly mortgage } \\
\text { payment (x100) }\end{array}$ & & $\begin{array}{c}-0.165 \\
(0.721)^{* *}\end{array}$ & $\begin{array}{c}-0.201 \\
(0.109)^{*}\end{array}$ & & \\
\hline Additional controls & $\begin{array}{l}\text { House Value }+ \\
\text { Loc. Prices }\end{array}$ & & & $\begin{array}{l}\text { House } \\
\text { Value }\end{array}$ & $\begin{array}{l}\text { House } \\
\text { Value }\end{array}$ \\
\hline $\begin{array}{l}\text { First-stage: Coeff. } \\
\text { (s.e.) on instrument }\end{array}$ & $\begin{array}{c}0.809 \\
(0.022)\end{array}$ & -- & $\begin{array}{c}0.604 \\
(0.008)\end{array}$ & -- & -- \\
\hline T-Stat on instrument & 37.25 & -- & 70.73 & -- & -- \\
\hline
\end{tabular}

Note: Regressions run on the monthly dataset. All regressions include year dummies; monthly dummies; SIC92 1-digit sector dummies; and individual controls. See notes to Table 2 for more details. Standard errors clustered at the LPA level. *: 10\% significant; **: 5\% significant. Loan-to-value (LTV) of outstanding mortgage calculated using outstanding amount of mortgage and individual's assessment of property value. LTV capped at 1.25; values above 1.25 recoded as missing. Monthly mortgage payment refers to the month prior to the interview (time varying, self-reported and measures in GB pounds). Instrumental variable regressions instrument individual's LTV with local LTV and individual log monthly mortgage payments with log of local monthly mortgage payments. Both measures are obtained using data from the Survey of Mortgage Lenders at the
LPA level. The instruments are time-varying and set to zero for years in which individuals are renters. Descriptive statistics of local LTV as follows. Mean=0.751;

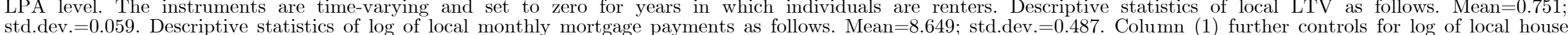
std.dev. $=0.059$. Descriptive statistics of log of local monthly mortgage payments as follows. Mean $=8.649 ;$ std.dev. $=0.487$. Column $(1)$ further controls for log of local house prices. Columns (4) 